\title{
NITROGEN AVAILABILITY TO WOODY PLANT SPECIES AS INFLUENCED BY NITROGEN FIXATION
}

\section{JULY 1972 - NUMBER 13}

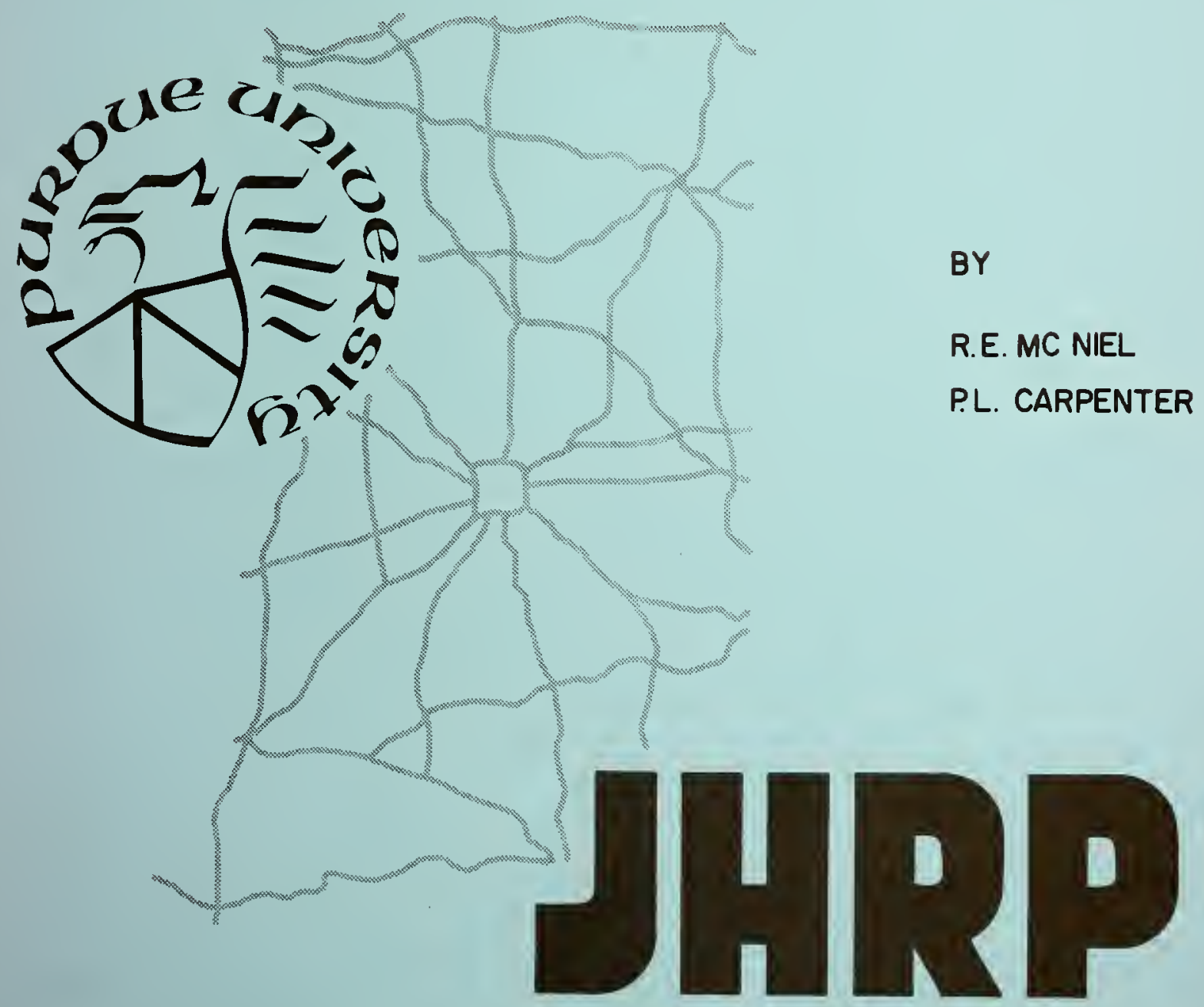

JOINT HIGHWAY RESEARCH PROJECT PURDUE UNIVERSITY AND

INDIANA STATE HIGHWAY COMMISSION 

TO: J. F. McLaugh1in, Director

Joint Highway Research Project

FROM: H. L. Michael, Associate Director Joint Highway Research Project
Ju1y 26,1972

Project: $\quad C-36-48 C$

File: $\quad 9-5-3$

The attached is the sixth and last Interim Report of 1972 on Part II of the HPR Research Project "Research in Roadside Development and Maintenance". This Report is titled "Nitrogen Availability to Woody Plant Species as Influenced by Nitrogen Fixation" and has been authored by Messrs. Robert E. MCNiel and Philip L. Carpenter.

The Report is submitted for acceptance as partial fulfillment of the objectives of this Study. It will also be submitted to the ISHC and the FHWA for review, comment and similar acceptance.

Respectfully submitted,

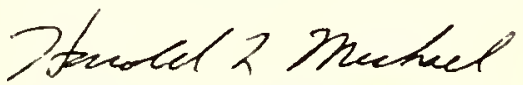

Harold L. Michael

Associate Director

HLM:ms

$\begin{array}{lll}\text { cc: W. L. Dolch } & \text { R. H. Harrell } & \text { C. F. Scholer } \\ \text { R. L. Eskew } & \text { M. L. Hayes } & \text { M. B. Scott } \\ \text { W. H. Goetz } & \text { C. W. Lovel1 } & \text { J. A. Spooner } \\ \text { W. L. Grecco } & \text { G. W. Marks } & \text { N. W. Steinkamp } \\ \text { M. J. Gutzwiller } & \text { R. D. Miles } & \text { H. R. J. Walsh } \\ \text { G. K. Hallock } & \text { J.W. Miller } & \text { E. J. Yoder }\end{array}$




\section{Interim Report \\ NITROGEN AVAILABILITY TO WOODY PLANT SPECIES \\ AS INFLUENCED BY NITROGEN FIXATION}

by

Robert E. McNiel

Graduate Assistant in Research

and

Philip L. Carpenter

Associate Professor

Department of Horticulture

Joint Highway Research Project

Project No.: $\mathrm{C}-36-48 \mathrm{C}$

File No.: $9+5-3$

Prepared as Part of an Investigation

Conducted by

Joint Highway Research Project

Engineering Experiment Station

Purdue University

In cooperation with the

Indiana State Highway Commission

and the

U.S. Department of Transportation

Federal Highway Administration

The contents of this report reflect the views of the author who is responsible for the facts and the accuracy of the data presented herein. The contents do not necessarily reflect the official views or policies. of the Federal Highway Administration. This report does not constitute a standard, specification, or regulation. 
Digitized by the Internet Archive in 2011 with funding from

LYRASIS members and Sloan Foundation; Indiana Department of Transportation 
TABLE OF CONTENTS

PAGE

LIST OF TABLES . . . . . . . . . . . . . . . . .

LIST OF FIGURES. . . . . . . . . . . . . . . . . .

INTRODUCTION ........................ . . . . 1

REVIEW OF LITERATURE . . . . . . . . . . . . . . . . . 2

Nitrogen Fixation . . . . . . . . . . . . . 2

Factors which influence nodule formation. . . . . . . 5

MATERIALS AND METHODS. . . . . . . . . . . . 6

Nitrogen Fixation . . . . . . . . . . . 6

Activity during Autum Months. . . . . . . . . 7

Nitrogen Supply as a Nurse Crop. . . . . . . . . 9

RESULTS AND DISCUSSION ................. 12

Nitrogen Fixation. . . . . . . . . . . . 12

Nitrogen Fixation by Members of the Leguminosae Family - 12

Nitrogen Fixation by non-1egume Trees and Shrubs ... . 13

Factors Effecting Nodulation. . . . . . . . . . 13

Temperature. . . . . . . . . . . . 13

Season .................... 25

Combined Nitrogen. . . . . . . . . . . 30

Nitrogen Fixing Plants Used as a Nurse Crop . . . . . . 30

SUMMARY AND CONCLUSIONS. . . . . . . . . . . . . . . 36

BIBLIOGRAPHY . . . . . . . . . . . . . . . . 38

APPENDIX . . . . . . . . . . . . . . . . . . 42 


\section{LIST OF TABLES}

TABLE

PAGE

1 Plant treatments which were grown on three solutions containing differ nt nutrient levels... . . . . . . 10

2 Nitrogen content of solutions in which nitrogen-fixing

plants were grown. . . . . . . . . . . . . 34 


\section{LIST OF FIGURES}

FIGURE

PAGE

1 Typical gas chromatographic curve showing peaks of ethylene and acetylene which had been injected as a acetylene - cthylene - air misutre . . . . . .

2 Reduction of acetylene by nodules from field grown Caragana arborescens on two different dates during 1971. . . . . . . . . . . . . .

3 Reduction of acetylene by nodules from greenhouse grown Robinia fertilis on five different dates during 1971. . . . . . . . . . . . . .

4 Reduction of acctylene by nodules of field grown Robinia hispida on three different dates during 1971....................

5 Effect of temperature on ability of Robinia Pseudoacacia nodules to reduce acetylene. . . . .

6 Reduction of acctylene by Alnus glutinosa nodules 8 hours after having been excised. . . . . . . .

7 Reduction of acetylene by nodules from greenhouse grown Elacagnus umbellata on three different dates during 1971. . . . . . . . . . • . . .

8 Reduction of acctylene by nodules from field grown Elaeagnus angustifolia on two different dates during 1971....................

9 Reduction of acetylenc by nodules from field grown Sherpherdia argentea on four sampling dates during 1971. . . . . . . . . . . . . . .

10 Reduction of acetylenc by nodules from greenhouse grown Sherpherdia canadensis on October 12, 1971...

11 Reduction of acetylene by nodules from greenhouse grown Hippophac rhamoides on September 9, 1971. . Myrica pensylvanica on two different dates during 1971............... 
13 Reduction of acetylene by nodules from greenhouse grown Alnus glutinosa on six different dates during 1971. . . . . . . . . . . . . .

14 Air and soil temperatures relating to nodule activity between October 9, 1971 and December 21, 1971...

15 Reduction of acetylene by nodules from field grown Alnus glutinosa at two time intervals during 6 months of 1971...............

16 Reduction of acetylene by nodules from 6 year and 12 year old Elaeagnus umbellata at two time intervals during 6 months of 1971..............

17 Nitrogen content of foliage of plants grown on three nutrient solutions. . . . . . . . . . . . 


\section{ABSTRACT}

Thirteen woody plant species were analyzed by acetylene reduction assay to determine their nitrogen fixation activity. Caragana arborescens, Lam., Robinia fertilis Ashe, R. hispida L., R. Pseudoacacia L., Alnus glutinosa (L.) Graettn., Elaeagnus umbellata Thunb., E. angustifolia L., Shepherdia argentea Nute., $\underline{\text { S. }}$ canadensis Nutt., Iippophae rhamoides L., and Myrica pensylvanica Lois. were found to be active.

Nodules carried out nitrogen fixation best under low nitrogen fertility while at higher rates of fertilization or low temperatures the nodules ceased to function. Temperatures, which caused $\underline{A}$. glutinosa and E. umbellata to defoliate, did not stop nodule activity at the time of defoliation.

Nodules on plants grown in a solution culture failed to excrete nitrogen into the growing medium. Therefore, it is believed increased nitrogen fertility around trees and shrubs which fix nitrogen is due to decomposing nodules and ieaf litter. 
INTRODUCTION

Nitrogen nutrition is vital to woody plant establishment. Meyer (27) explained how nutrient supplies during the preceding year and current spring were important to shoot growth and leaf production in any specific year. He also reported $(28,29)$ nitrogen reserves seemed to be the limiting factor for growth on a deciduous and an evergreen species.

Plants produce nitrogen supplies through a symbiotic relationship with a micro-organism. Symbiotic nitrogen fixation by non-legume woody plants has not been widely known nor has the knowledge been used by the nursery or landscape industry. Root nodules have been observed on some non-legume woody species for over a century but like trees and shrubs from the Leguminosae family little is known about the quantities of nitrogen a plant has the potential of supplying for itself or adjacent non-nitrogen fixing species.

Thus when conditions were optimum for plant growth, shoot development would be aided by adequate nitrogen and in turn hasten plant establishment in the highway landscape. The biological process of nitrogen fixation has the potential of supplying adequate nitrogen for plant establishment and development. Thus, the landscape architect should consider plant material with nitrogen fixation characteristics when choosing plant material for various highway sites. 
REVIEW OF LITERATURE

\section{Nitrogen Fixation}

Symbiotic nitrogen fixation occurs most abundantly in the Leguminosae family. Cercis, Gleditsia, Gymocladus, Cladrastis, Sophora, Laburnum, Amorpha, Wisteria, Robinia and Caragana are legume genera which contain ornamental trees and shrubs (33) important in Indiana. Although not all species within the Leguminosae family develop nodules, approximately one-tenth of the 12,000 species have been identified with development of nodular structures (1).

As can the agronomic crops such as alfalfa and soybean, legume trees and shrubs may also be inoculated with bacteria to insure nodulation (17). However, the bacteria for the woody plants is not a member of any of the six cross-inoculation groups used with alfalfa, clover, or soybean (1).

Symbiotic nitrogen fixation also occurs with less known frequency among eight families which contain only thirteen genera and 342 species of which 118 are known to develop root nodules (34). The thirteen genera include: Alnus, Ceanothus, Hippophae, Elaeagnus, Myrica, Casuarina, Shepherdia, Coriaria, Dryas, Discaria, Purshia, Cercocarpus, and Arctostaphylos.

Unlike the legumes the symbiotic organism is not known. It is not a Rhizobium association but may be an actinomycete (19). This is not 
the feeling of all investigators. Hawker and Fraymouth (22) have classified it as a member of the Plasmodiophorales. Since the organism has not been isolated, there is no commercial product available for inoculation of non-legume woody plants.

An interesting history as to the possible importance of nonleguminous symbiotic nitrogen fixation has developed during the past twenty-five years. Extensive work has established (7, 13, 14, 25) a pattern of plant succession that has developed behind receding glaciers. These reports include Alnus as an early plant and attribute part of the soil nitrogen build up to the Alnus' nitrogen fixing ability. Kohnke (24) has advocated the use of Alnus in reclamation of mines, sand dunes and other waste areas. His citation includes examples of success on waste soils in Germany and Japan. Goldman (21) attributed the productivity of a lake to the nitrogen supplied by the Alnus growing along its banks.

The importance of non-legume nitrogen fixation for today's crops comes from evidence reported of the association of Alnus rugosa (Du Roi) Spreng. with confiers (3) and of the association of Alnus glutinosa (L.) Graettn. with Malus (16).

In the case of Alnus being established after glacier recession, the rate of accumulation of nitrogen in relation to age of plant was linear for 40 years (13). Where $\mathbf{A}$. rugosa was included in the succession of a douglas-fir forest, nitrogen accumulation peaked at 20 years (31). These plants were being established on a soil with some fertility and 
organic matter. The area of establishment had been cut for a crop or destroyed by fire.

Nodular material on legumes is spherical or cylindrical in shape with a few or no lobes. With non-legumes the nodular material forms clusters of finger-like branches (8). The clusters are perennial and with age may attain a diameter of several centimeters (8). In the genera Myrica and Casuarina there is an exception to the normal cluster. With nodules from these genera the tip of the branch continues to produce a root of normal structure without nitrogen-fixing characteristics (9). Nodules were identified on non-legumes as early as 1829, (10) and since then a few investigators have used field studies or no nitrogen solution-cultures to grow plants and then determine their nitrogen content of the foliage. From this method of nitrogen analysis the plants were classified as nitrogen fixing plants. Shepherdia argentea (38) and Elaeagnus angustifolia (20) have been identified in this manner. When $\mathrm{N}^{15}$ bccame available several species were analyzed to determine the quantity of nitrogen transformed by the plant. Species identified with positive nitrogen fixation mechanisms included: $\underline{\text { A. }}$ glutinosa $(4,5)$, Hippophae rhamnoides L. (4), Shepherdia canadensis Nutt. (6), Comptonia peregrina (L.) Coult. (41). A method of analysis which costs less has become available--the acetylene reduction assay. By this method $\underline{A}$. rugosa, $\underline{A}$. glutinosa, $\underline{\underline{M}}$. gale, and $\underline{\mathrm{C}}$. peregrina have been determined to reduce acetylene to ethylene $(35,39)$. 
By the $\mathbb{N}^{15}$ technique Bond (6) found $\underline{H}$. rhamnoides and A. glutinosa to increase fixation in a linear manner. $\underline{H}$. rhamnoides was active longer and produced a linear response for approximately 24 hours. Stewart also reported (35) the fixation by $\underline{C}$. peregrina to be linear for 60 minutes when using the acetylene reduction assay.

\section{Factors Which Influence Nodule Formation}

Fluctuation in the rate of nitrogen fixation has been observed for $\underline{\text { C. peregrina, }}$ A. glutinosa, and $\underline{\mathrm{M}}$. gale $(35,39)$. Stewart (35) observed ethylene production by nodules sampled in the morning to be only half the value of nodules sampled in the afternoon. Wheeler (40) found that a peak in nitrogen fixation was reached about mid-day. He explained the reason for the peak at this time, was because there was a maximum influx of new photosynthate into the nodule, and only when new photosynthate is available does fixation occur.

Virtanen (37) demonstrated that with leguminous plants the photosynthetic substrate must be translocated to the nodule. The substrate supplied energy for fixation while at the same time accepted the nitrogen. Little is known on how rapidly the substrate is exhausted after photosynthesis ceases.

Bond and associates $(11,26)$ have demonstrated with non-leguminous plants that nodule size and weight in relation to the parent plant is dependent upon the external nitrogen supply. With $100 \mathrm{mg}$ of combined 
nitrogen in solution culture nodules will cease to form, however, with Iess nitrogen the nodules will form with the largest being when no nitrogen is available. Similiar results were found on $\underline{A}$. rugosa (14). Quispel (32) has also found that ammonium salts inhibit nodule formation sooner than nitrates.

MATERIALS AND METHODS

\section{Nitrogen Fixation}

Nitrogen fixation by both legume and non-legume woody species was determined. When nodules were available for analysis, fixation was determined by acetylene reduction assay as determined by Davidson (15). An exception to the procedure was that the nodules were analyzed over a period of several hours and not every ten minutes for an hour as described by Davidson. The thirteen species observed included five legumes (Robinia hispida L., R. fertilis Ashe, R. Pseudoacacia L., Caragana arborescens Lam., and Cercis canadensis L.) and eight species of non-legumes (Elaeagnus umbellata Thunb., E. angustifolia L., Shepherdia argentea Nutt., S. canadensis, Hippophae rhamoides, Alnus glutinosa, Myrica pensylvanica Lois., and Comptonia peregrina).

Plants of these species were grown in the greenhouse in a sphagnum peat: horticultural grade perlite mixture $(1: 1 \mathrm{v} / \mathrm{v})$ or in the ficld. In no case was there an attempt to innoculate a plant 
that did not bear nodules. Nodules were removed from plants up to twelve years in age.

Samples were gencrally taken during mid-morning work hours during the summer of 1971. In the case of the non-legumes the nodules were divided and only the tips of the branches were used. The base of the branch or center part of the cluster was discarded. The legume nodules were left intact except when to large to be put into a $18 \mathrm{ml}$ culture tube. In this case they were divided. All nodules were washed with tap water to remove soil particles and then blotted dry in a paper towel prior to weighing.

\section{Activity During Autumn Months}

Figure 1 shows a standard gas chromatograph curve obtained from a mixture of pure acetylene, ethylene, and air. The values for the peaks on cach sampling date werc computerized. With the use of linear regression a computer program developed a formula for a straight line using the values from the standard curve. The peak height response of each unknown sample injected was placed in the straight 1 ine formula to determine the microliters of ethylene produced. The peak response was linear with ethylene concentration.

Nodules from field grown $\underline{A}$. glutinosa and $\underline{\text { E. umbellata were }}$ analyzed for acetylenc reduction periodical1y from late sumer 1971 until December 1971. This experiment was initiated to observe nodule 


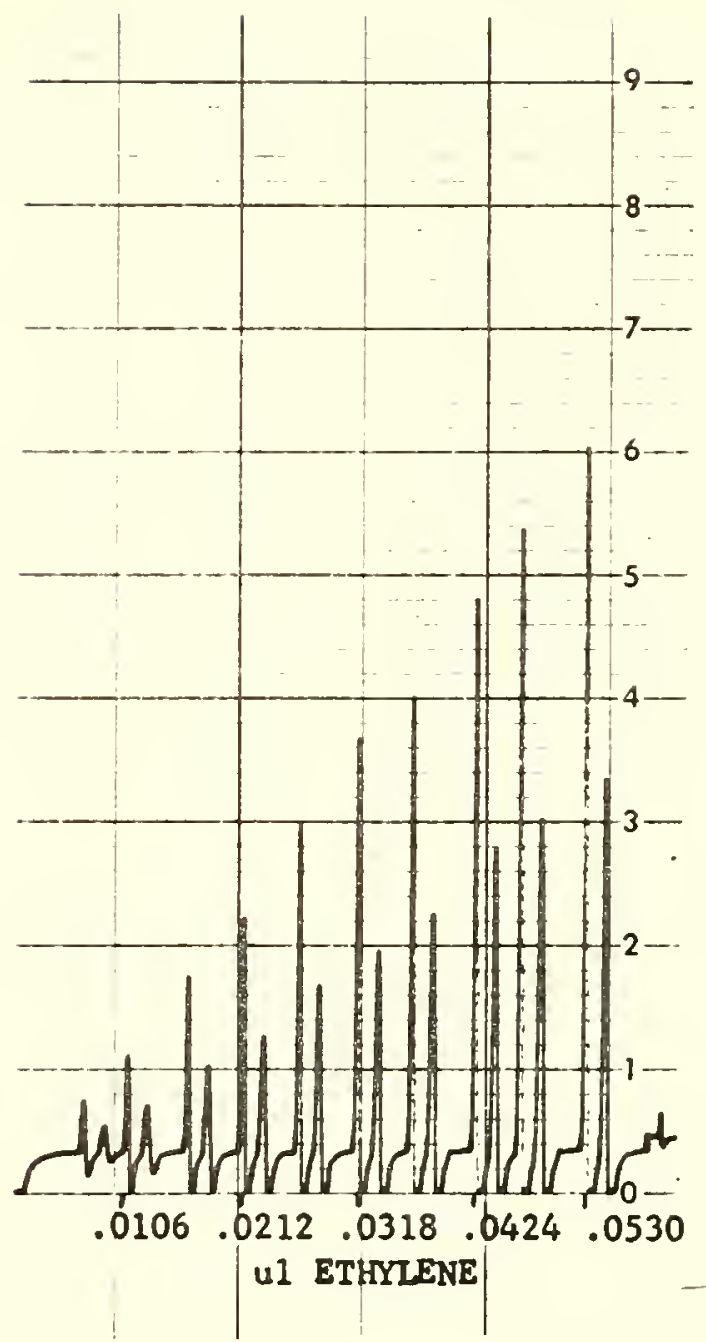

Figure 1. Typical gas chromatographic curve showing peaks of ethylene and acetylene which had been injected as a acetylene - ethylene air mixture. 
activity from month to month, and determine how late into a growing season nitrogen fixation would take place.

No nodules were removed from the same plant of either $\underline{A}$. glutinosa or $\underline{E}$. umbellata. The $\underline{A}$. glutinosa were two year old seedling and lacked enough material for several samples, and the six and twelve year old E. Lmbellata were in a location where their root systems could not be seriously distrubed. The method for preparing the nodules for analysis was the same as mentioned above.

\section{Nitrogen Supply as a Nurse Crop}

This experiment was designed to determine the effect that nitrogenfixing nodules would have on plants which were unable to carry out symbiotic nitrogen-fixation. Virtanen (36) claimed A. glutinosa nodules had provided a nitrogen supply to spruce grown in solution culture for eleven years. To determine if this was possible for other plant relationships, four nitrogen-fixing plant species were selected to be grown separately and in combination with two non-symbiotic species. Fifteen treatments (Table 1 ) including actively growing and nodulated

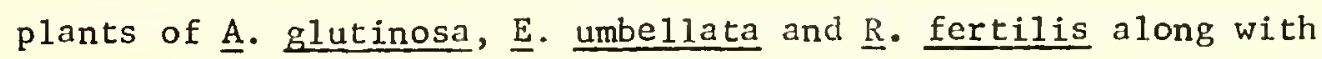
leafed out Cotoneaster divaricata Rehd. \& Wils., dormant E. angustifolia and seed of Poa pratensis "Nugget" were planted in 10.51 iter pots on August 3, 1971. The plants were grown in a polystyrene bead medium with three levels of fertilization and water being supplied by a 
Table 1. Plant treatments which were grown on three solutions containing different nutrient levels.

No. Treatment

Common name

1. Contro1

2. Alnus glutinosa

B1ack alder

3. Elaeagnus umbellata

Auturn olive

4. Elaeagnus angustifolia

Russian olive

5. Robinia fertilis

Bristly locust

6. Poa pratensis "Nugget"

Kentucky bluegrass var.

Nugget

7. Cotoneaster divaricata

Spreading cotoneaster

8. A. glutinosa and p. pratensis "Nugget"

9. A. glutinosa and C. divaricata

10. E. umbellata and $\underline{\text { P. pratensis }}$ "Nugget"

11. E. umbellata and $\underline{C}$. divaricata

12. E. angustifolia and $\underline{\underline{P}}$. pratensis "Nugget"

13. E. angustifolia and $\underline{C}$. divaricata

14. ‥ fertilis and $\underline{\text { P. pratensis }}$ "Nugget"

15. R. fertilis and C. divaricata 
sub-irrigation method. The three nutrient solutions were: (1) normal Hoagland solution, (2) no nitrogen Hoagland solution, (3) no nitrogen Hoagland solution with ten per cent of the nitrogen of a normal solution added as ammonium nitrate (23). Hoagland's micronutrients plus EDTA iron supplemented all three solutions. The woody species were able to support themselves, but a 10 fiber mat was placed on top of the pot to support the seed.

From the bottom of each pot extended a glass tube which was connected by tubing to a glass bottle below the bench. The glass bottle contained $3000 \mathrm{ml}$ of one of the three nutrient solutions. The bottle was also attached to an air line, and air pressure was applied with the use of an air pump and time clock so as to force the solution up out of the bottle five times a day. By use of a needle valve on the pump and timing the duration of operation, the pressure was regulated to move the solution to the top of the pot located on the bench above. Approximately $1500 \mathrm{ml}$ of the $3000 \mathrm{ml}$ solution could be removed by transpiration and evaporation before air would escape through the pot. As needed, additional solution was added. The solution in the bottle was discarded and replaced in approximately 14 weeks. The experiment was terminated 4-5 weeks later. Analytical work was carried out to determine the ability of the nodules to reduce acetylene and to determine the nitrogen content of the plant foliage and solutions. Nodule preparation and acetylene reduction assay were conducted as indicated before. Total nitrogen analysis of the foliage was with a modified 
micro-kjeldahl and steam distillation method using salicylic acid in the digestion (30).

\section{RESULTS AND DISCUSSION}

\section{Nitrogen Fixation}

Approximately 100 per cent of all symbiotic plants observed posscsed nodules. Specics exceptions were with Cercis canadensis which showed no evidence of nodules and with Comptonia peregrina which had the remains of nodules which were no longer active. $\underline{C}$. canadensis has been reported to be a legume which does not form nodules (17).

Differences in color were apparent between nodules possessing various degrees of activity. Nodules with high rates of acetylene reduction were bright in color. Colors ranged from a orange-red on Alnus to a distinct white on Elaeagnus. Bond (18) had reported differences in color on nodules from A. glutinosa. He believed this was due to the amount of light the nodule received. Bond also attributed the red color of the nodules of Alnus and Myrica to anthocyanin.

Nitrogen Fixation by Members of the Leguminosae Family

Nodules were obtained from four species of legumes and submitted to acetylene reduction assay for determination of the plants nitrogen fixing 
ability. Caragana arborescens (Fig. 2), Robinia fertilis (Fig. 3), R. hispida (Fig. 4), and $\underline{\text { R. Pseudoacacia }}$ (Fig. 5) each gave responses over several hours. This is longer than was reported by Aprison for legumes (2). He found two hours of activity to be the maximum for excised nodules.

Nitrogen Fixation by Non-1egume Trees and Shrubs

A. glutinosa nodules fixed nitrogen for several hours after being excised. Nodules injected with acetylene after being separated from the plant for eight hours still reduced acetylene after nine hours (Fig. 6). These findings are comparable to those of Bond (4). Acetylene reduction assay on nodules from Elaeagnus umbellata (Fig. 7), E. angustifolia (Fig. 8), Shepherdia argentea (Fig. 9), S. canadensis (Fig. 10), Hippophae rhammoides (Fig. 11). and Myrica pensylvanica (Fig. 12) all showed activity.

Factors Effecting Nodulation

Temperature

Robinia Pseudoacacia responded differently when grown at two temperatures. At the higher temperature $\left(16.5^{\circ} \mathrm{C}\right)$, growth was vigorous and the nodules proved to be active (Fig. 5). At $2.8^{\circ} \mathrm{C}$ the plants were 


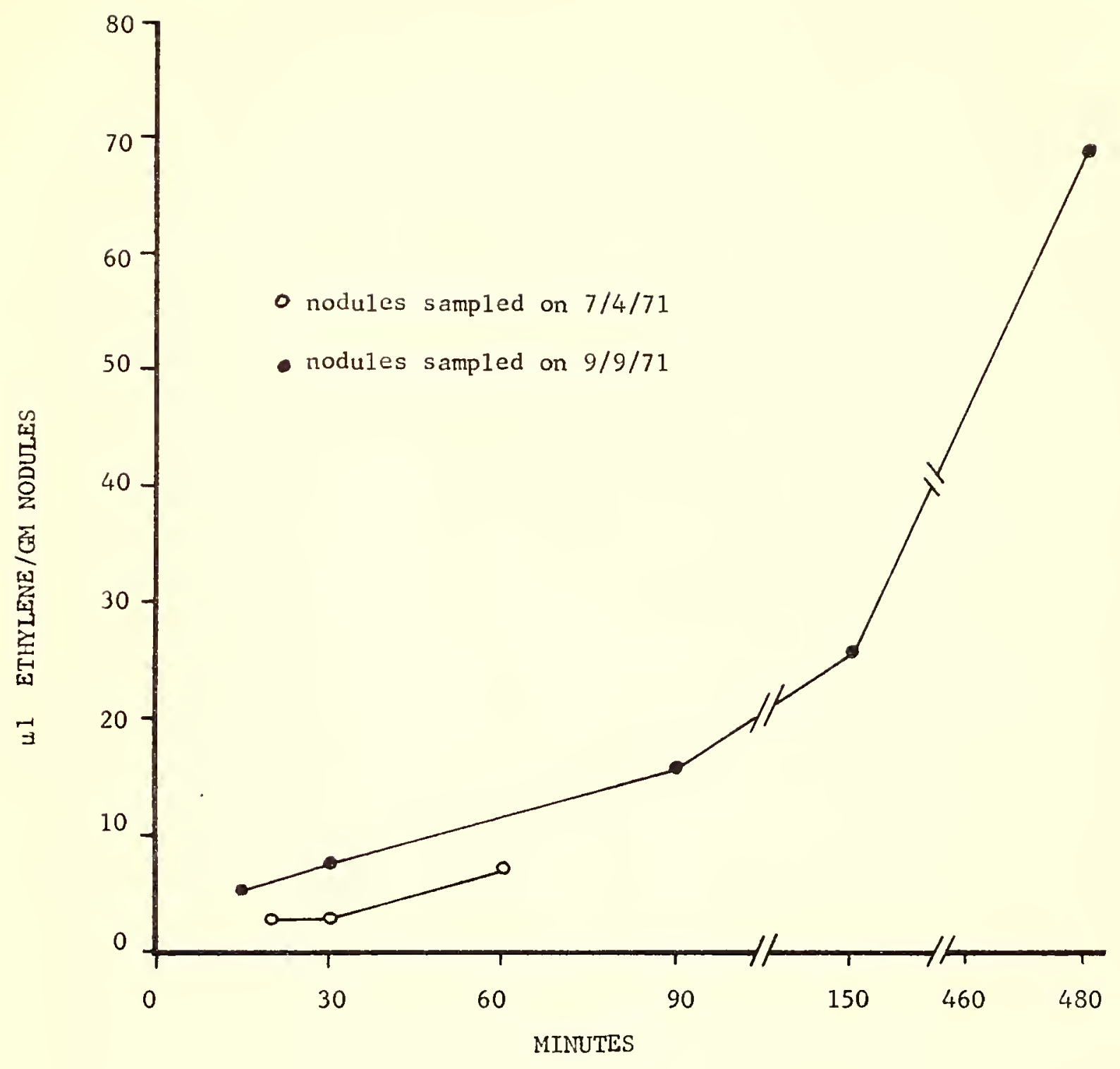

Figure 2. Reduction of acetylene by nodules from field grown Caragana arborescens on two different dates during 1971. 


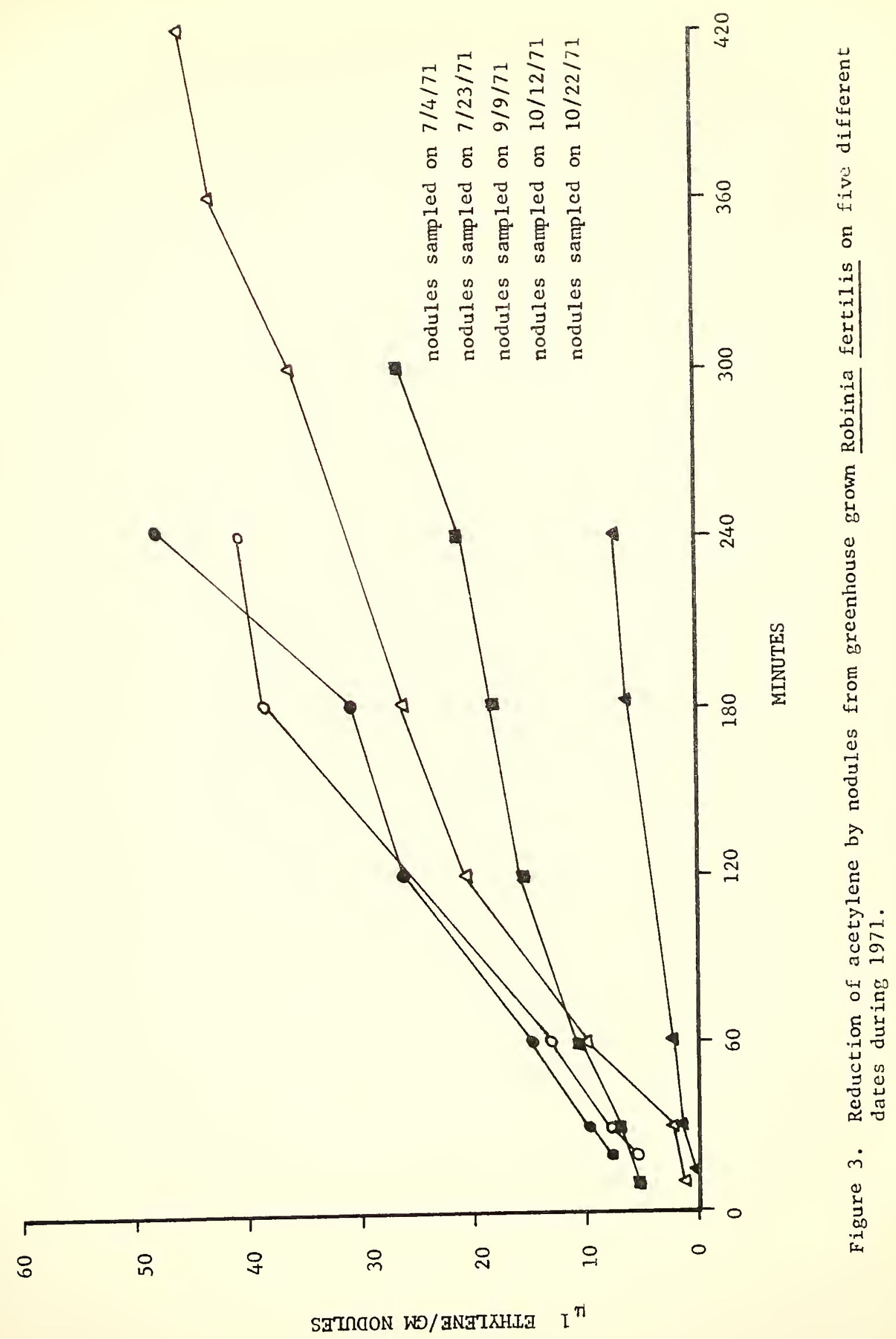




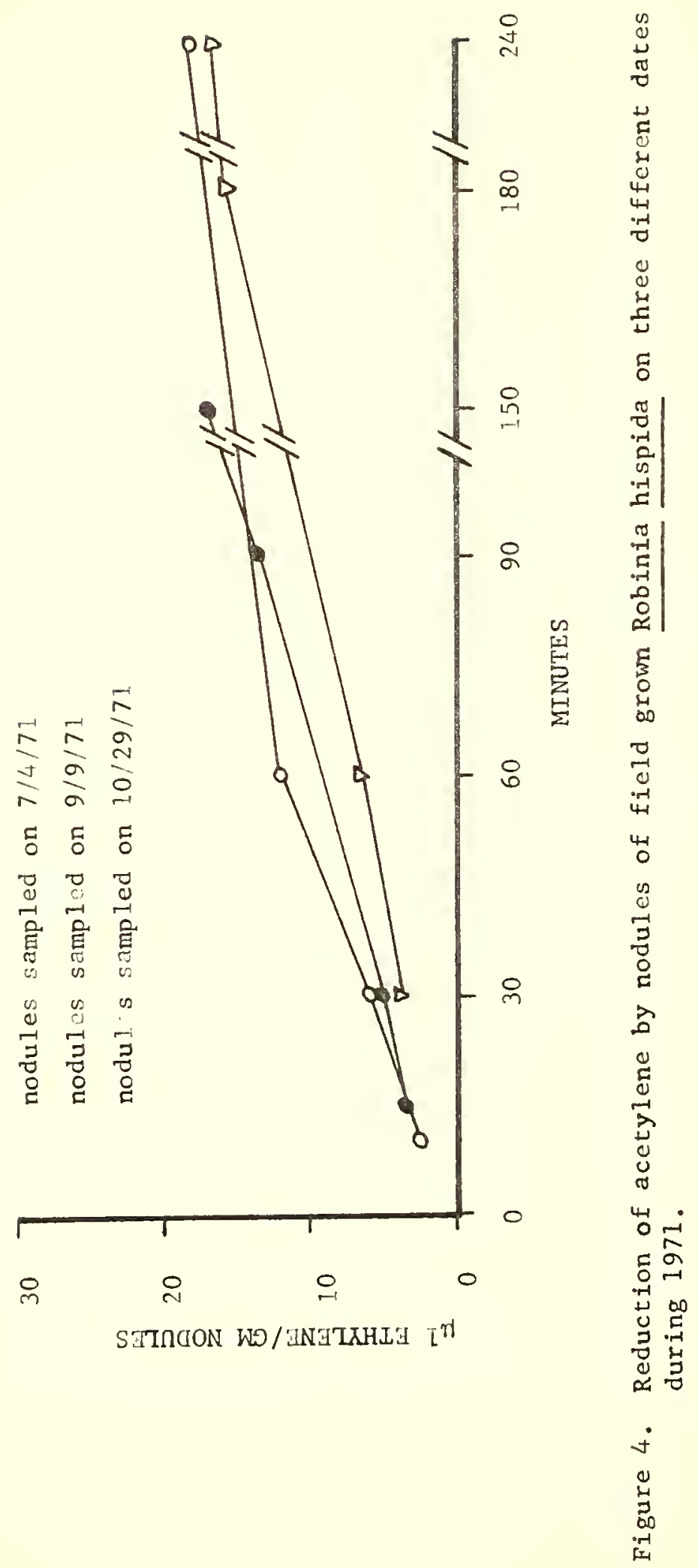




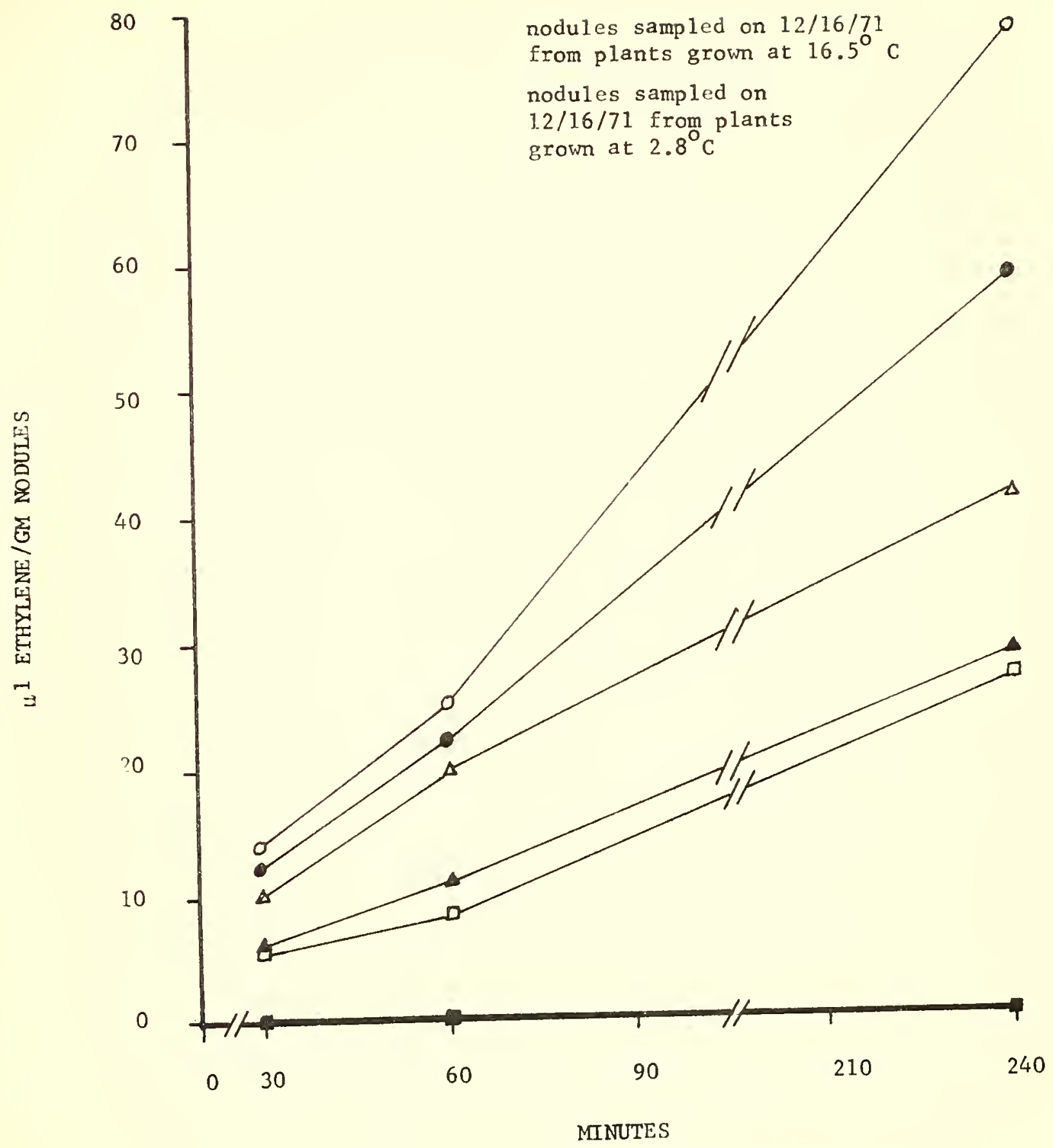

Figure 5. Effect of tempcrature on ability of Robinia Pseudoacacia nodules to reduce acetylenc. 


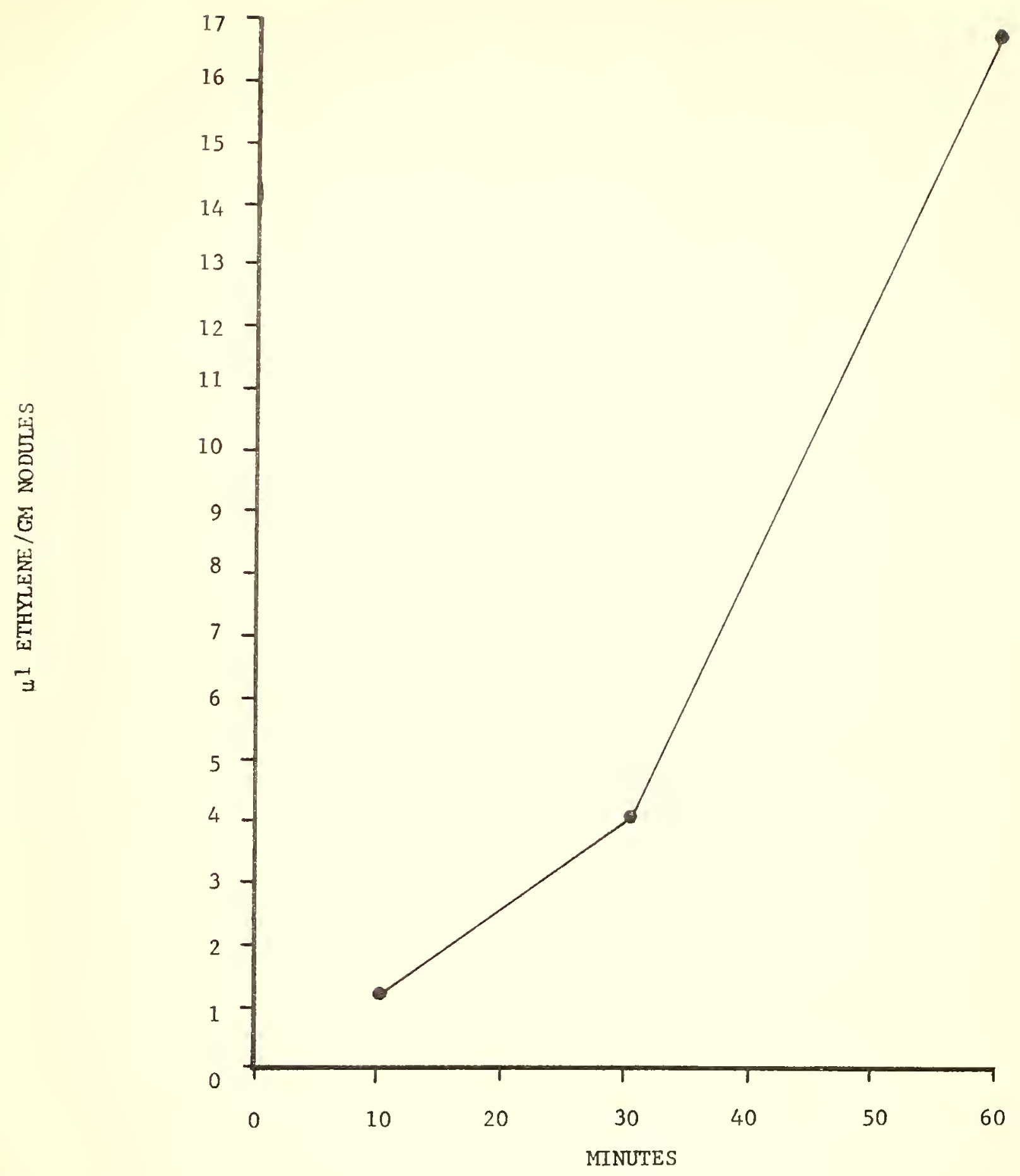

Figure 6. Reduction of acetylene by Alnus glutinosa nodules 8 hours after having been excised. 


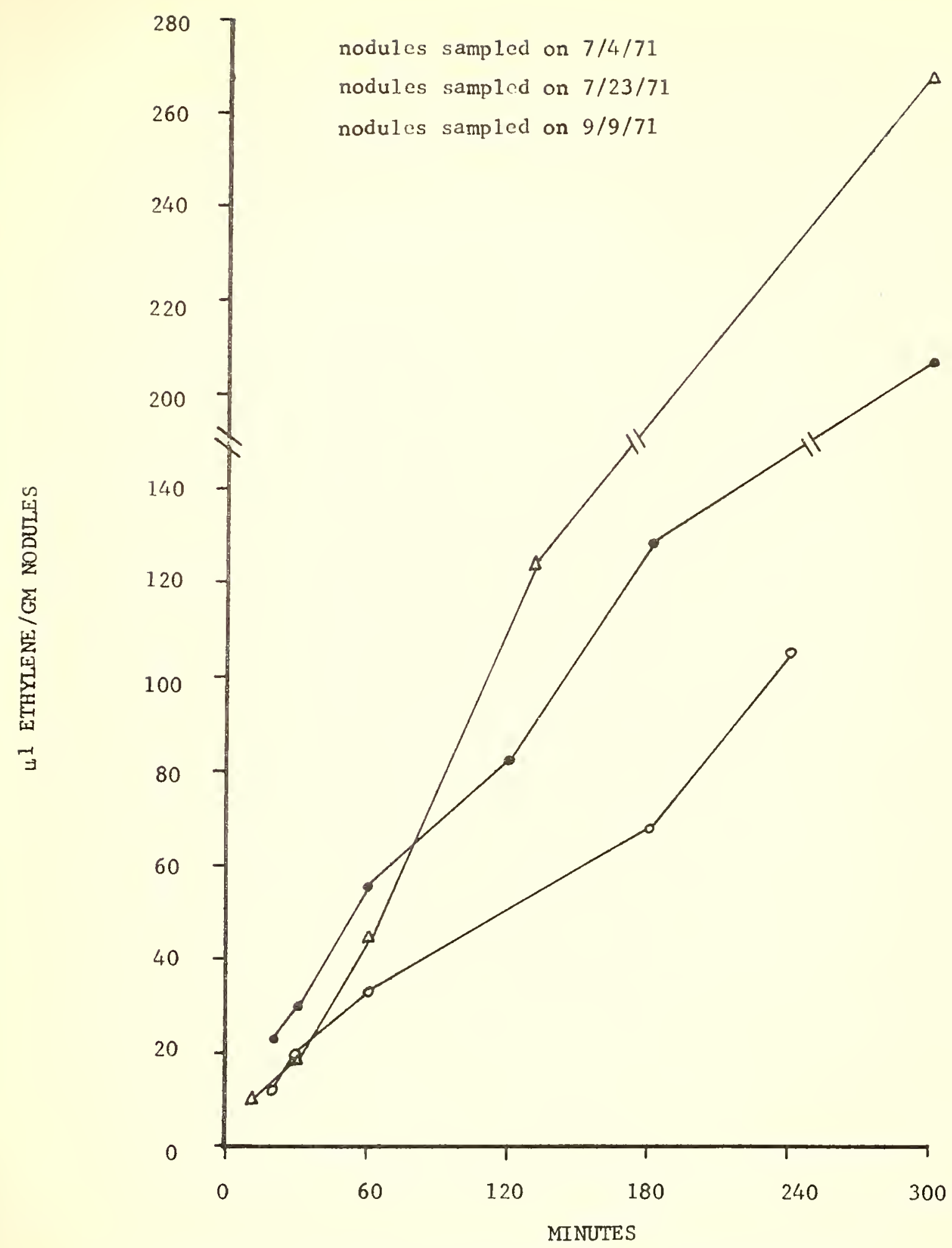

Figure 7. Reduction of acetylene by nodules from greenhouse grown Elaeagnus umbellata on three different dates during 1971. 


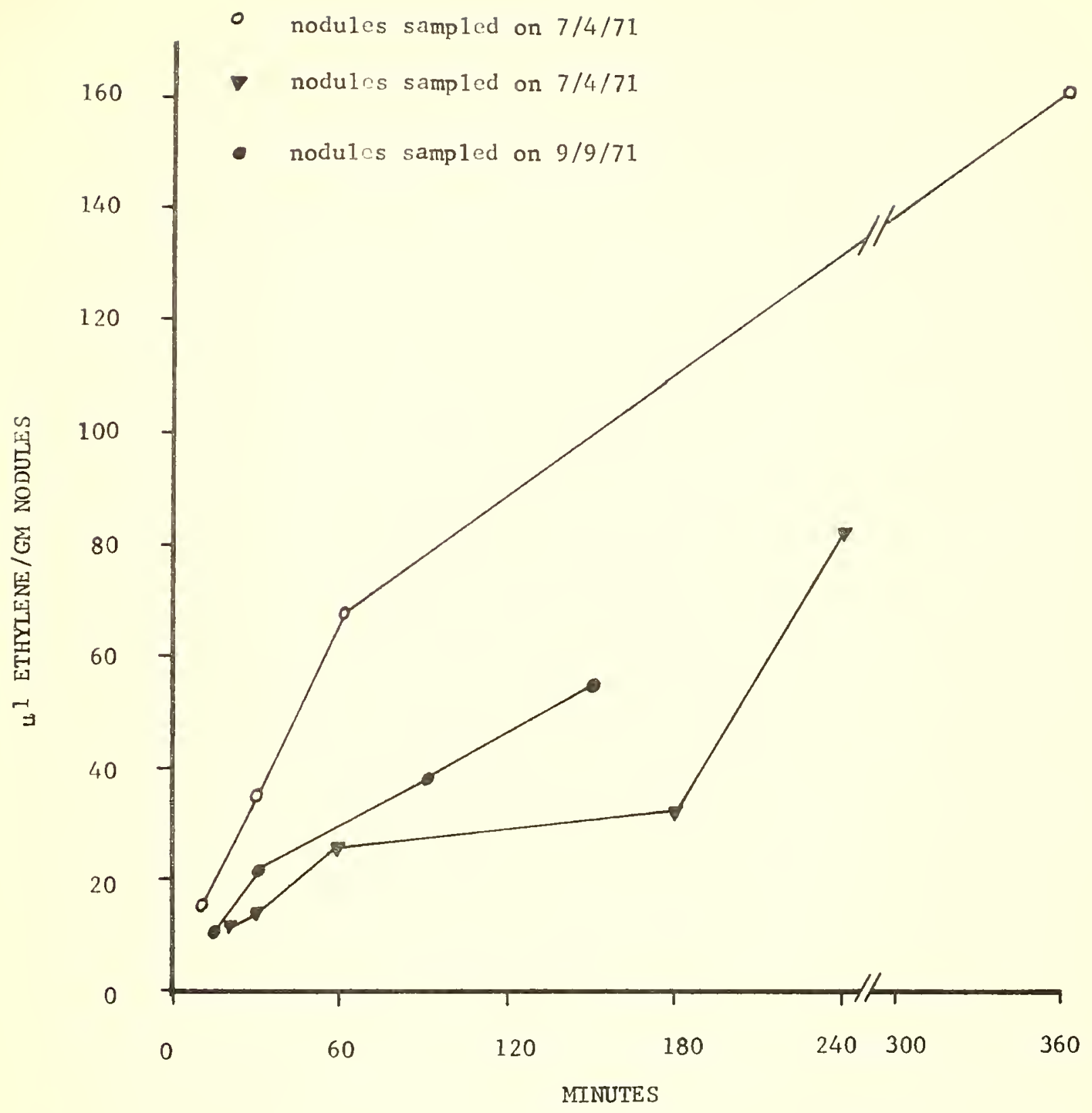

Figure 8. Reduction of acetylene by nodules from field grown Elaeagnus angustifolia on two different dates during 1971. 


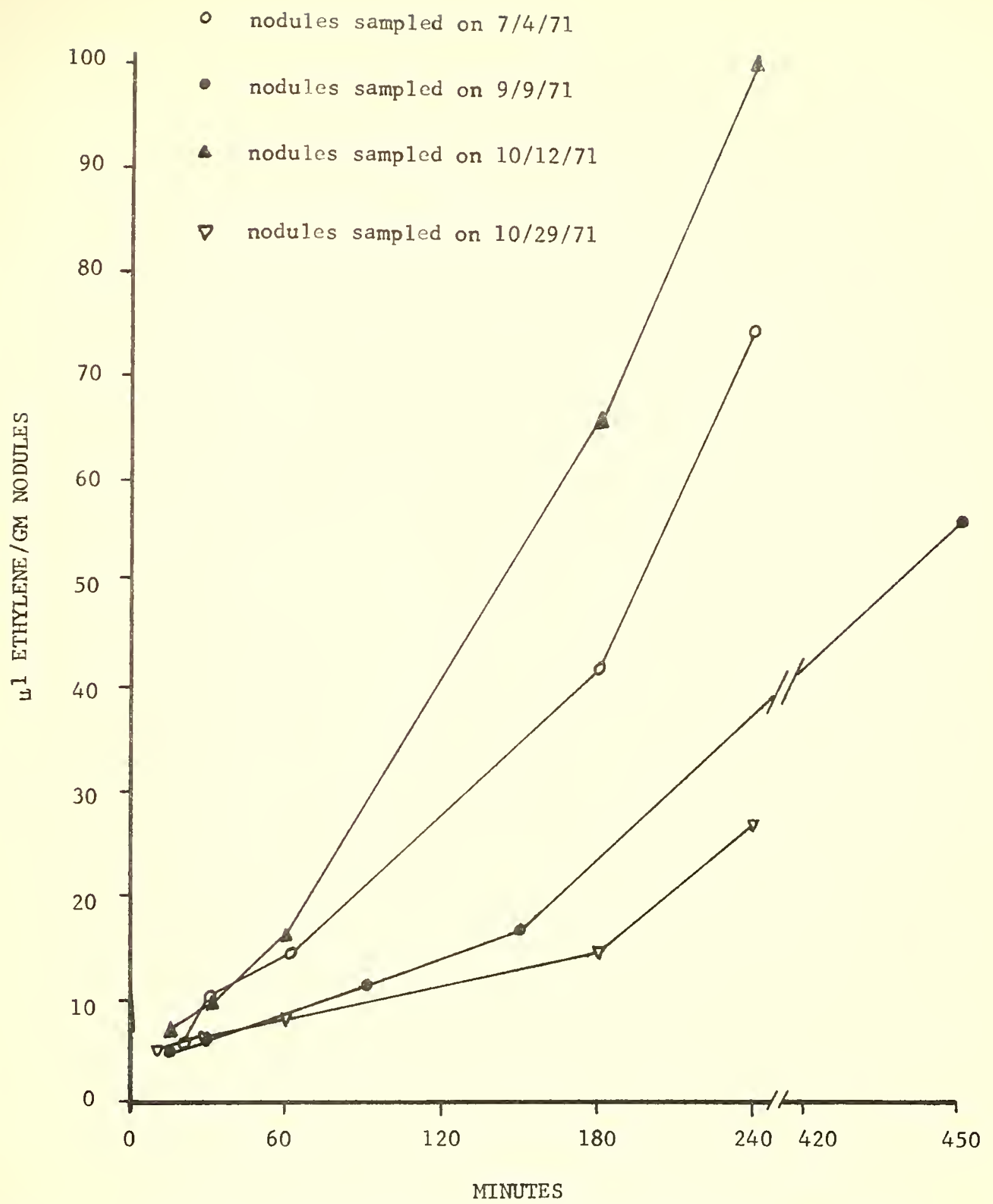

Figure 9. Reduction of acetylene by nodules from field grown shepherdia argentea on four sampling dates during 1971. 


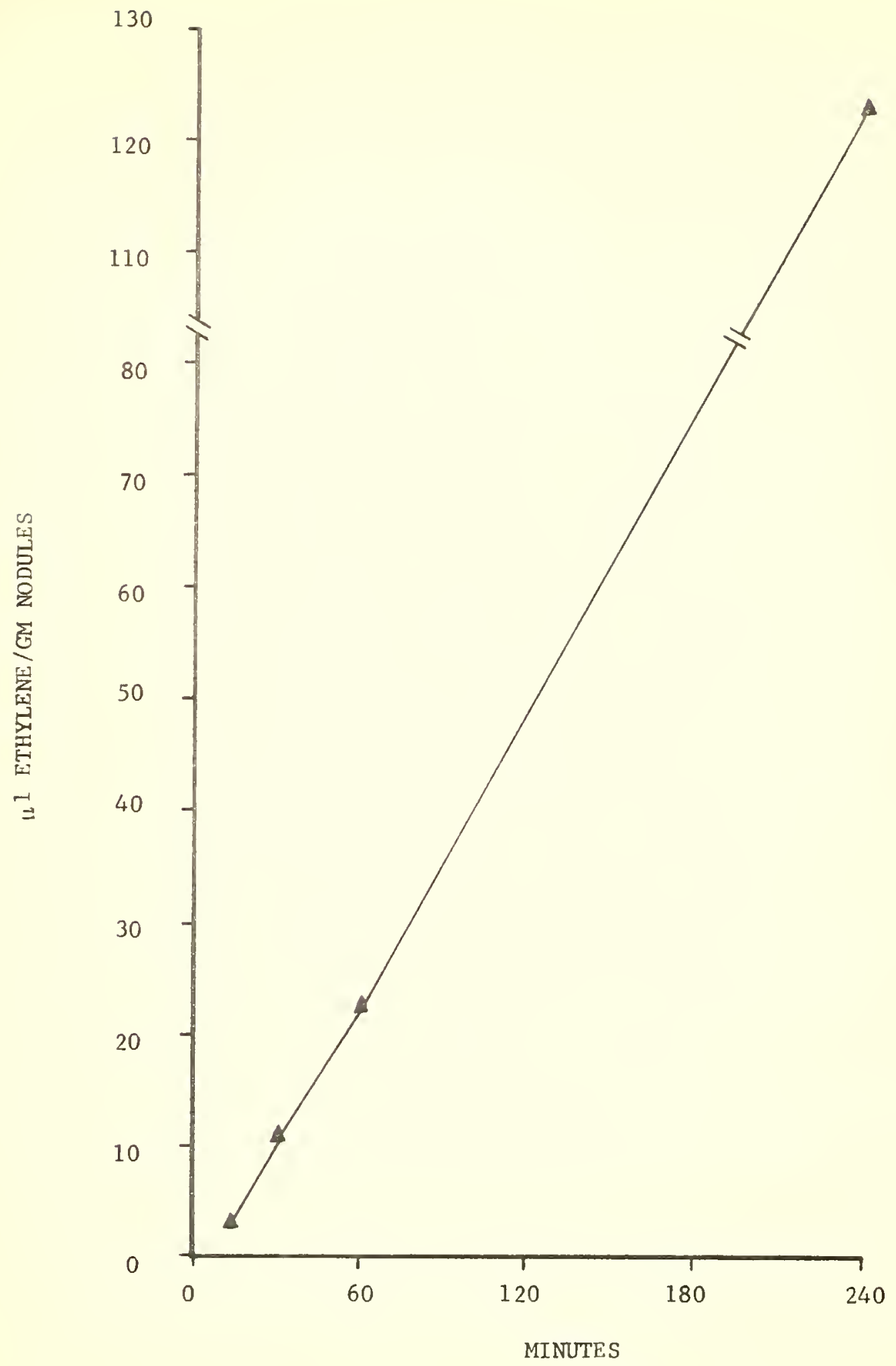

Figure 10. Reduction of acetylene by nodules from greenhouse grown Shepherdia canadensis on October 12, 1971 . 


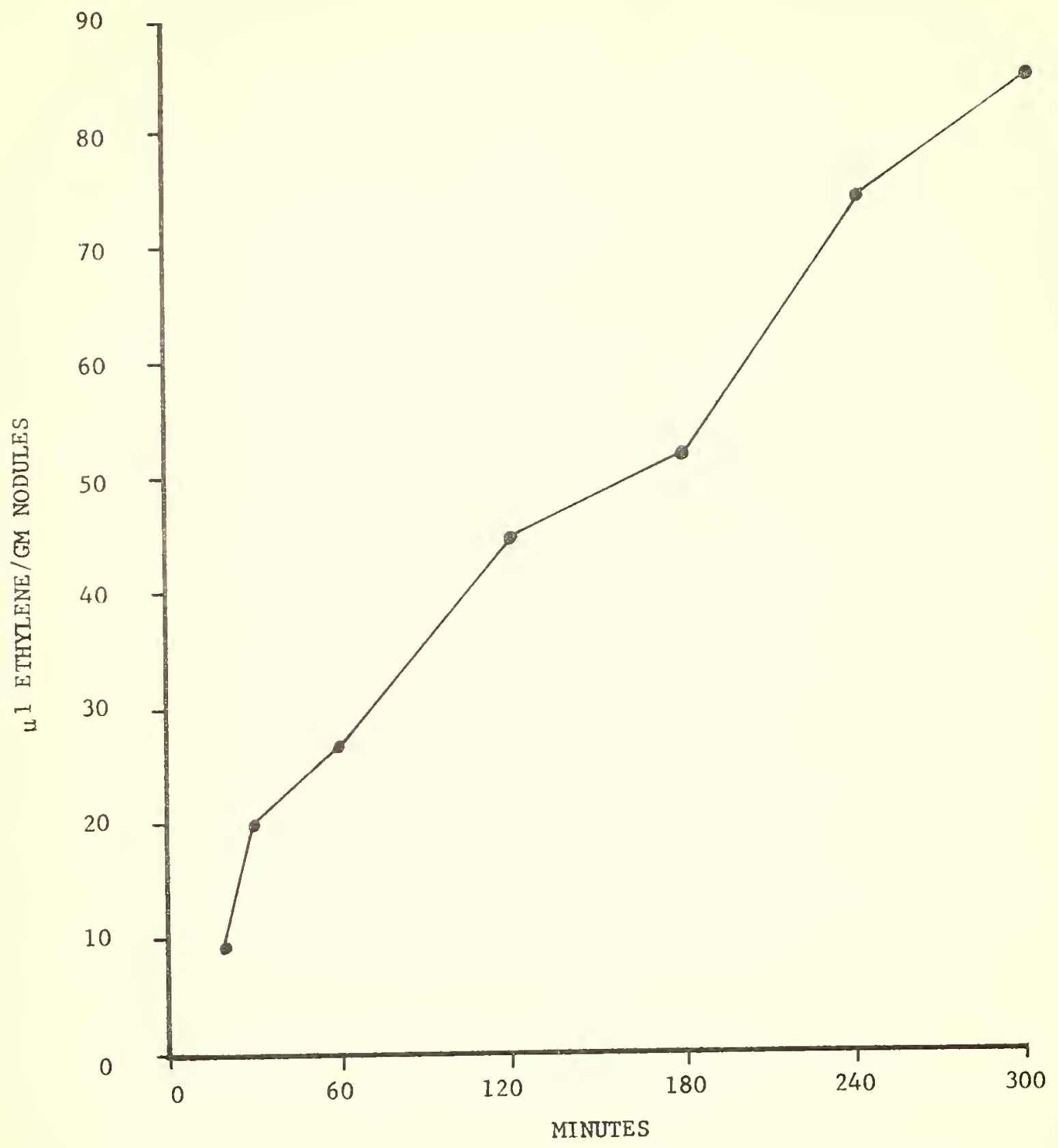

Figure 11. Reduction of acetylene by nodules from greenhouse grown Hippophae rhamoides on September 9, 1971. 


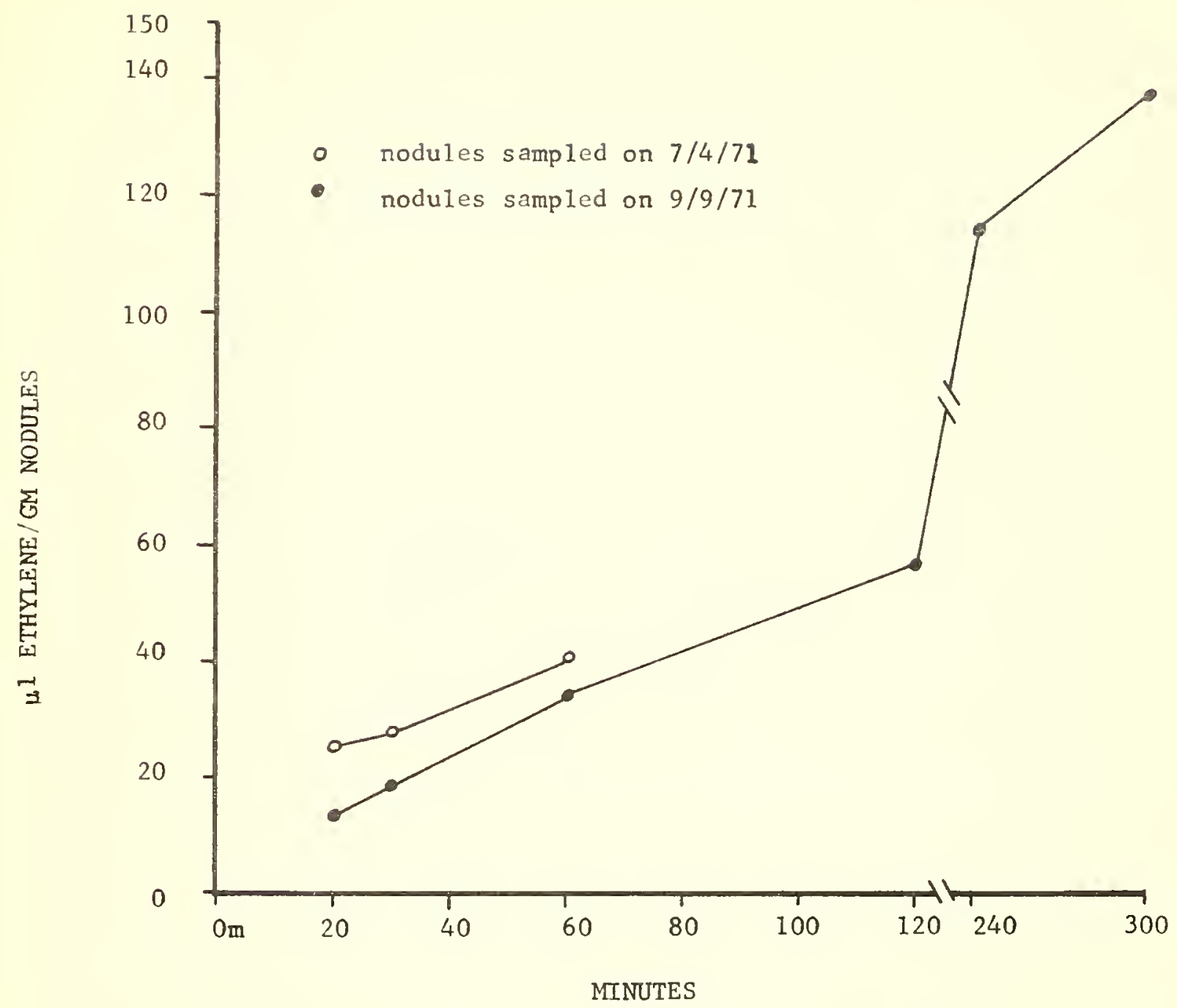

Figure 12. Reduction of acetylene by nodules from field grown Myrica pensylvanica on two different dates during 1971. 
in full leaf but not growing vigorously and the nodules, which werc active prior to the temperature treatment, did not maintain their activity (Fig. 5). The loss of activity could be due to a decrease in the rate of symthesis by the biochemical pathways of metablolism. At the low rate the substrates produced may be too few for the nodules to function.

\section{Season}

Nodules from $\underline{\text { A. }}$ Iutinosa reduced acetylene (Fig. 13) but tended to rcduce less during the fall dates as compared to the summer dates. This reduction in activity may have been due to less photosynthate being produced during the fall months.

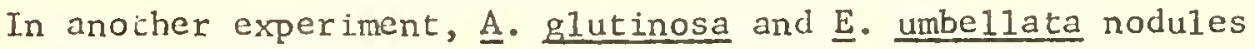
were removed from the top $5 \mathrm{~cm}$ of the soil beneath the plant. The A. glutinosa had been cultivated so little mulch existed. The E. umbellata nodules were protected from frost by $2-3 \mathrm{~cm}$ of 1 eaf 1 itter or mulch. The fall was warm with the first below $0^{\circ} \mathrm{C}$ air temperature recorded on November 4, 1971 and a severe freeze occuring on November 7, 1971 (Fig. 14) (12). The twelve year old plants of E. umbellata and the A. Glutinosa lost their leaves immediately while the six year old plants of $\mathrm{E}$. umbellata were protected by a windbreak and lost the 1r leaves gradually during the following two weeks. Activity did occur in the nodules for 5-6 weeks after the 1eaves dropped, however, 


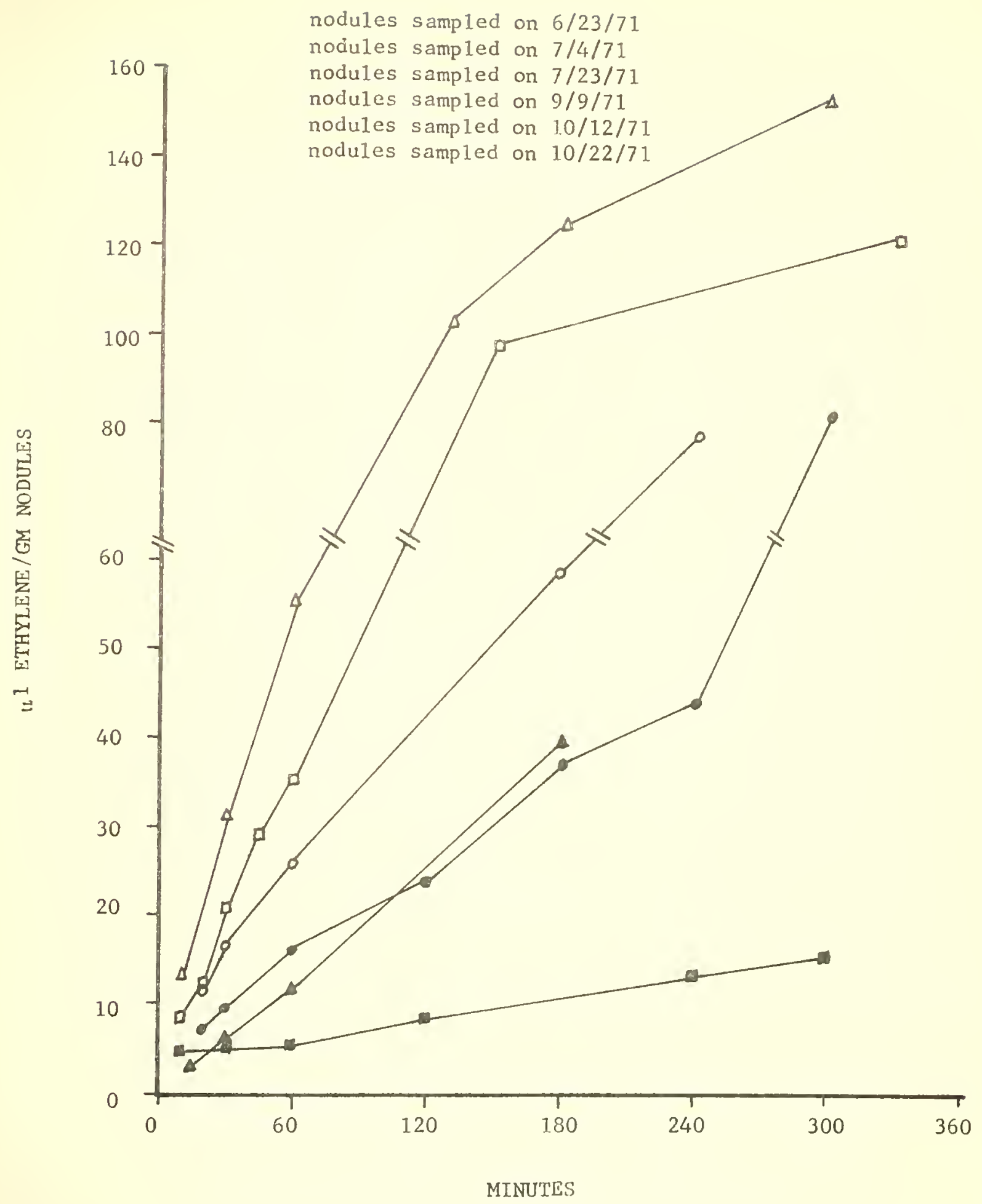

Figure 13. Reduction of acetylene by nodules from greenhouse grown Alnus glutinosa on six different dates during 1971. 


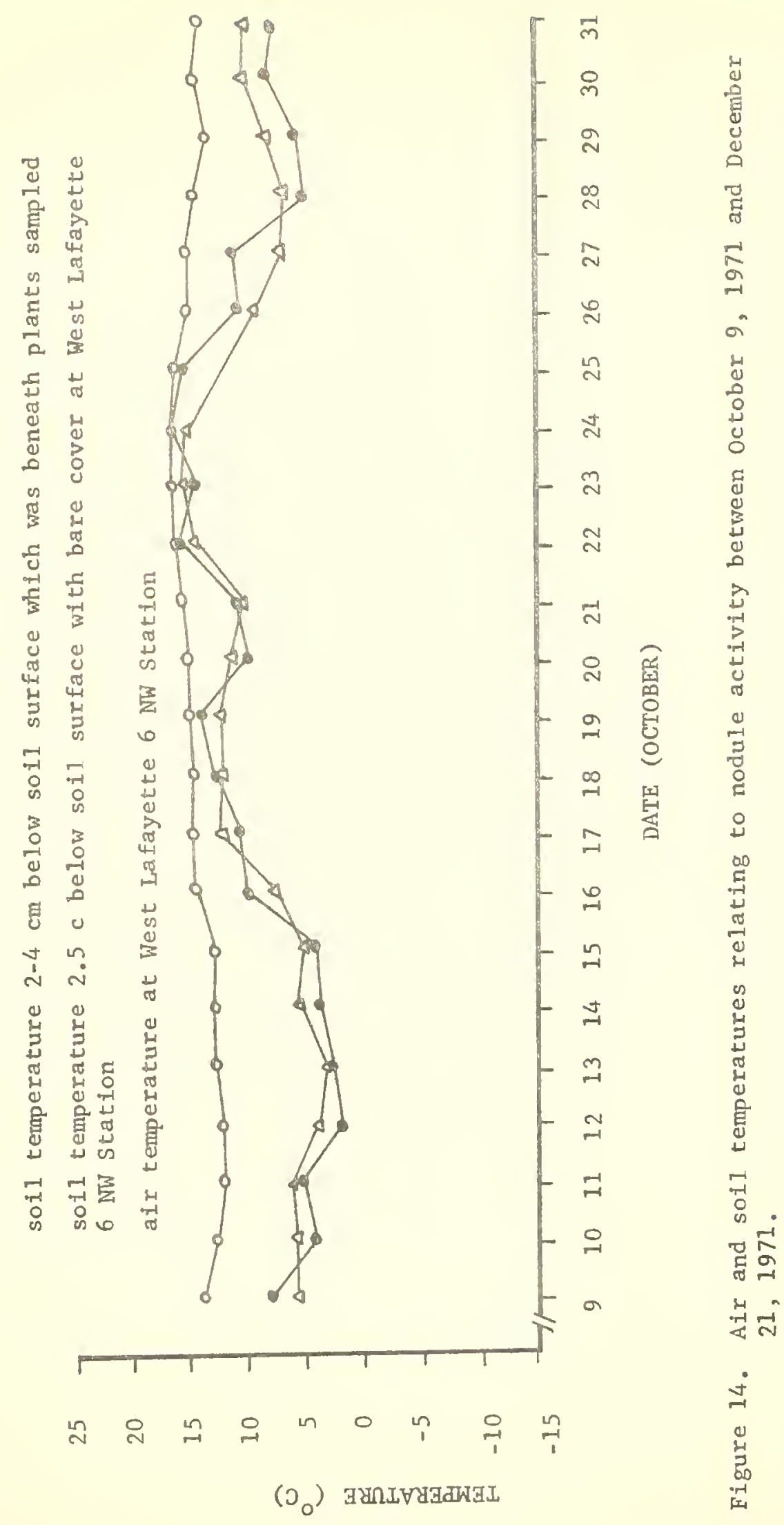




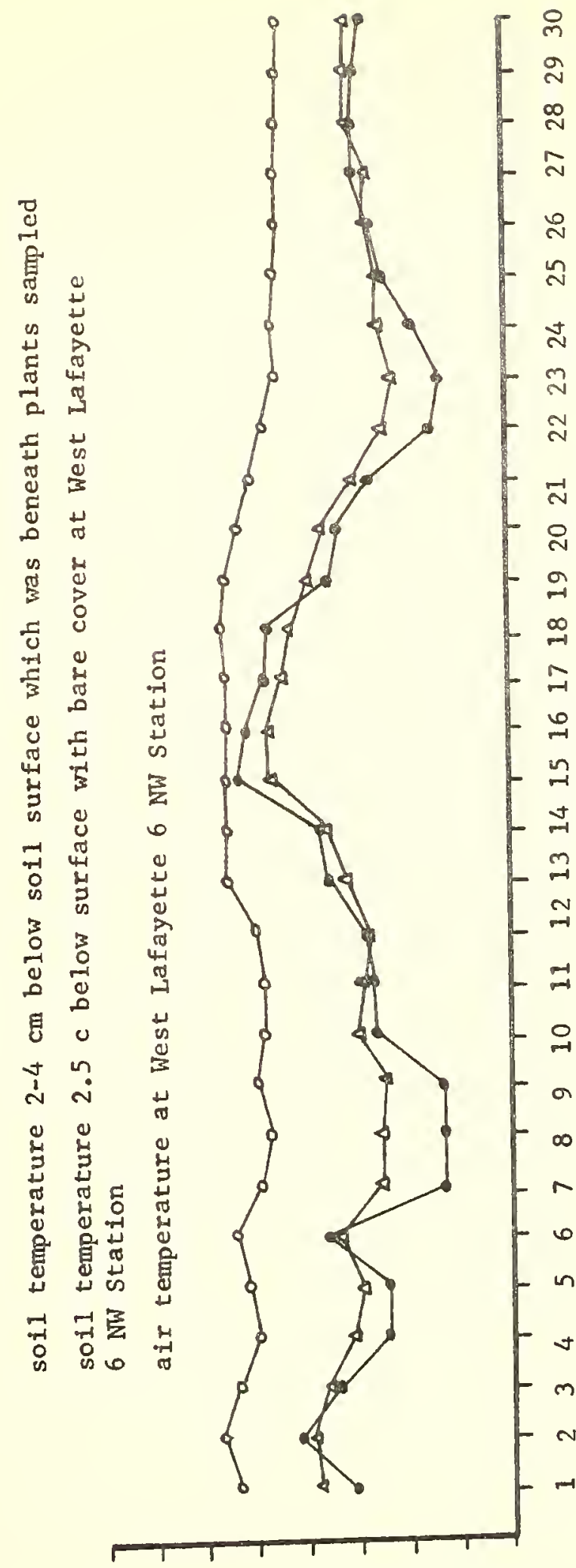

酎

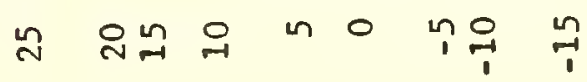

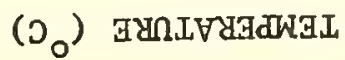

总 


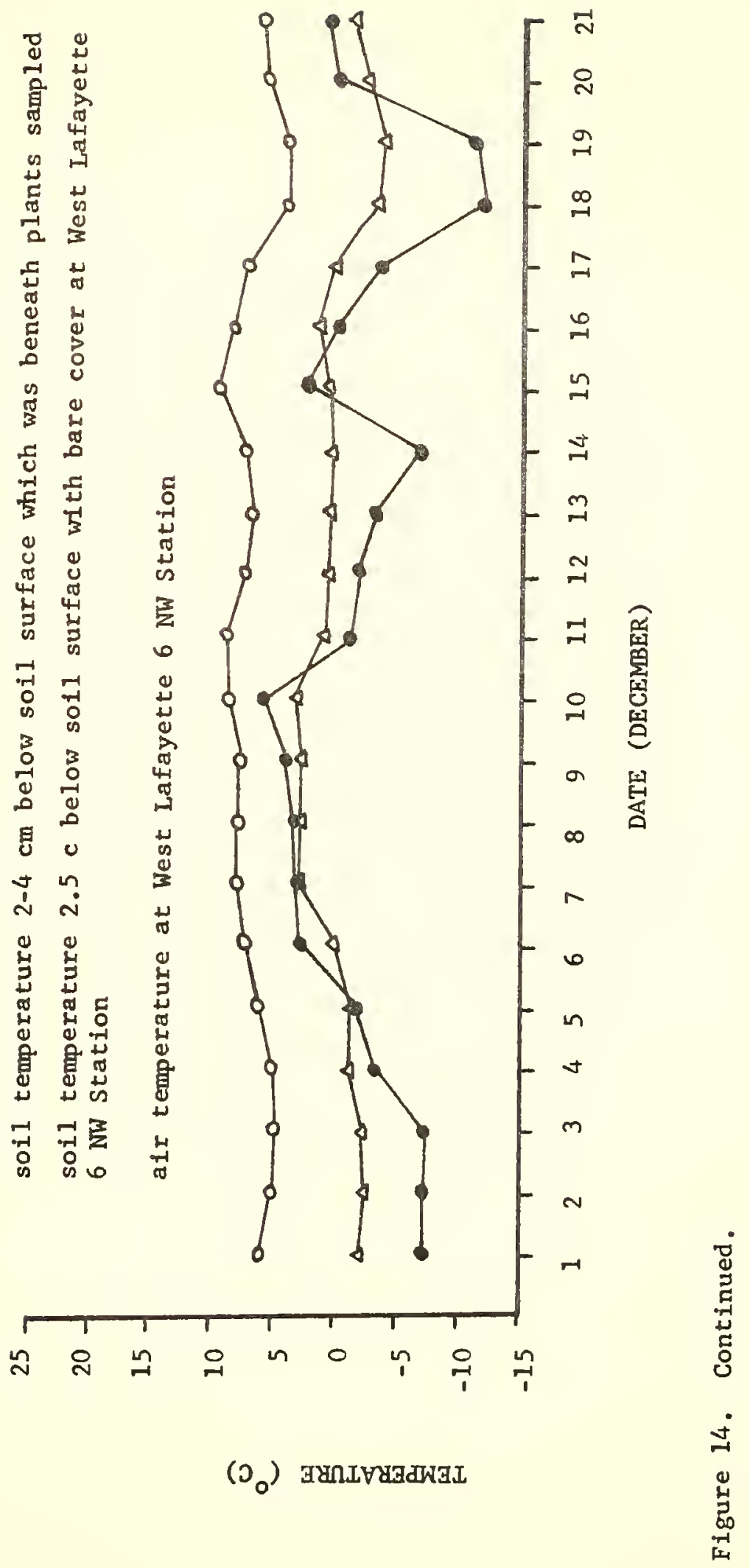


this activity was at a greatly reduced rate (Fig. 15, Fig. 16).

\section{Combined Nitrogen}

The plant condition of $\underline{A}$. 过utinosa, E. angustifolia, and $\underline{E}$. umbellata was usually good or excellent when grown in the normal strength Hoagland's solution. However, at this nutrient level nodules did not form when grown in the two solutions with low or no nitrogen, good and excellent plant growth was usually accompanied by active nodules on the plant root system (App. Table 1A).

When plants with active nodules were placed in the solution culture pots at planting time the nodules ceased to be active at the nitrogen level of the normal solution. The nodules from nonlegume plants (A. glutinosa, E. angustifolia and $\underline{E}$. umbellata) grown on either a low nitrogen or no nitrogen nutrient level responded according to the health of the parent plant. When plant condition remained good or excellent the nodules remained active with both of the lower nutrient levels. The legume shrub (․․ fertilis) ceased having active nodules even at the lower two levels.

Nitrogen Fixing Plants When Used as a Nurse Crop

The use of nitrogen fixing plants to supply nitrogen to the external medium did not prove successful. The low and no nitrogen solutions 


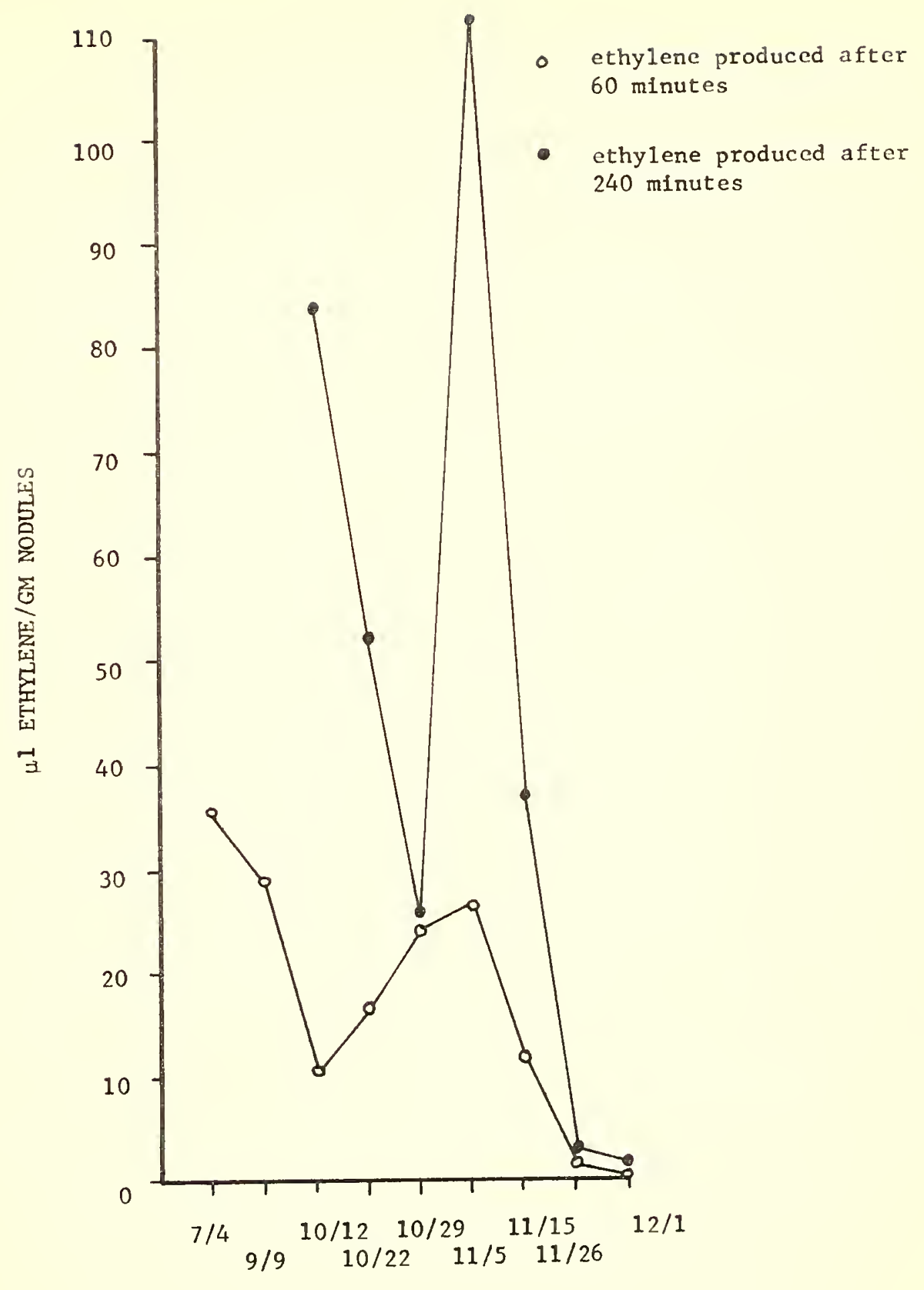

DATE

Figure 15. Reduction of acetylene by nodules from field grown Alnus
glutinosa at two time intervals during 6 months of 1971. 


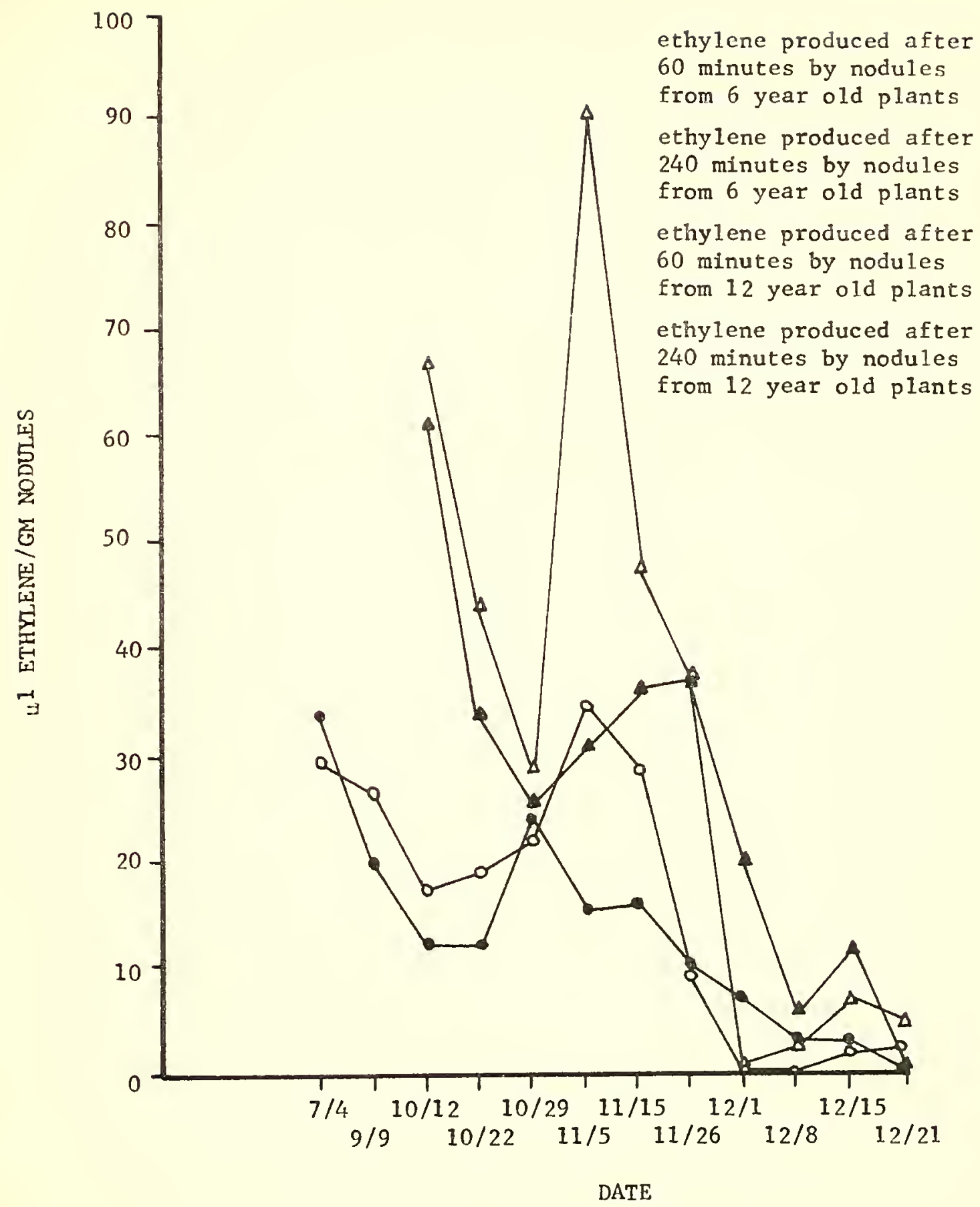

Figure 16. Reduction of acetylene by nodules from 6 year and 2 year old Elaeagnus umbellata at two time intervals during 6 months of 1971 . 
showed no significant increase in nitrogen (Table 2), thus indicating the nodules would not supply nitrogen to a solution or soil. In general the nitrogen supply of the low nutrient leve1 was depleted during the fertilization period. The nitrogen in the normal solution increased with the amount depending on plant growth per pot. As the plant grew, the stock solution was resupplied. With additional solution a build up occurcd because more nitrogen was available than the plant used.

Plant survival was not 100 per cent. $\underline{\text { P. pratensis "Nugget" never }}$ produced a good stand and did not survive. The companion plants used enough solution that the fluctuation in the level the solution in each pot varied frequently at the time the pot was full and when additional solution was added. The seed being at the top of the pot would go through periods of being wet and then dry, and if germination did occur, the seedlings did not survive. With the woody plants, losses werc atrributed to death during dormancy and transplanting or to mechanical failure of the system. In the case of $\underline{E}$. angustifolia plants did not leaf out and with the other species losses generally occurred shortly after having been transplanted. In a few instances death was due to broken glassware or loose connections.

The nitrogen content of the foliage from the woody species was greatest on those plants grown on normal Hoagland's solution (Fig. 17). With a few plant treatments, the nitrogen content of the foliage gave no significant difference between plants grown on the three different 
Table 2. Nitrogen content of solutions in which nitrogen-fixing plants were grown.

Solution

Treatment

Norma 1 Low No

nitrogen nitrogen nitrogen

ppm nitrogen
A. glutinosa
$\begin{array}{lll}452.04 & 2.70 & .25\end{array}$
E. angustifolia
$277.24 \quad 22.27 \quad 4.64$
R. fertilis
$\begin{array}{lll}453.61 & 12.10 \quad .56\end{array}$
E. umbe11ata
$\begin{array}{lll}560.23 & .70 \quad 2.23\end{array}$
P. Pratensis "Nugget"
$\begin{array}{lll}382.61 & 1.91 & .43\end{array}$
C. divaricata
$\begin{array}{lll}349.03 & 3.74 & .36\end{array}$
No plant
$\begin{array}{lll}276.56 & 10.93 \quad .70\end{array}$
A. glutinosa and $\underline{P}$. Pratensis "Nugget"
$\begin{array}{lll}640.47 & 1.82 & .25\end{array}$
A. Slutinosa and C. divaricata
$495.32 \quad 5.77 \quad .65$
E. angustifolia and $\underline{P}$. pratensis "Nugget"
314.77
3.47
.27
$\underline{E}$ angustifolia and $\underline{\mathrm{C}}$. divaricata
304.29
$4.44 \quad 1.60$
R. Eertilis and $\underline{P}$. pratensis "Nugget"
438.29
4.55
.47
R. fertilis and $\underline{\text { C. divaricata }}$
408.36
1.84
.25
E. umbellata and $\underline{\text {. }}$. pratensis "Nugget"
544.43
3.43
1.15
E. umbellata and $\underline{\text {. divaricata }}$
$535.79 \quad 14.47$
1.37 


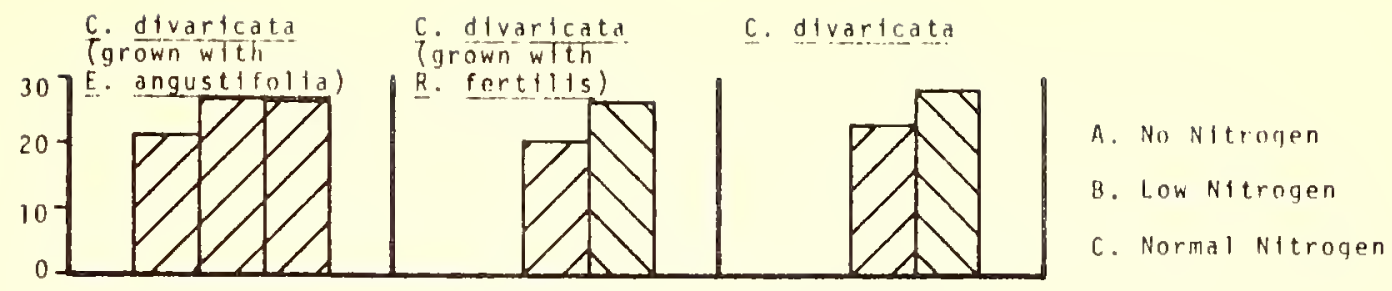

A. glutinosa

A. quidutinosa

p. pratensis)

Tgrown with

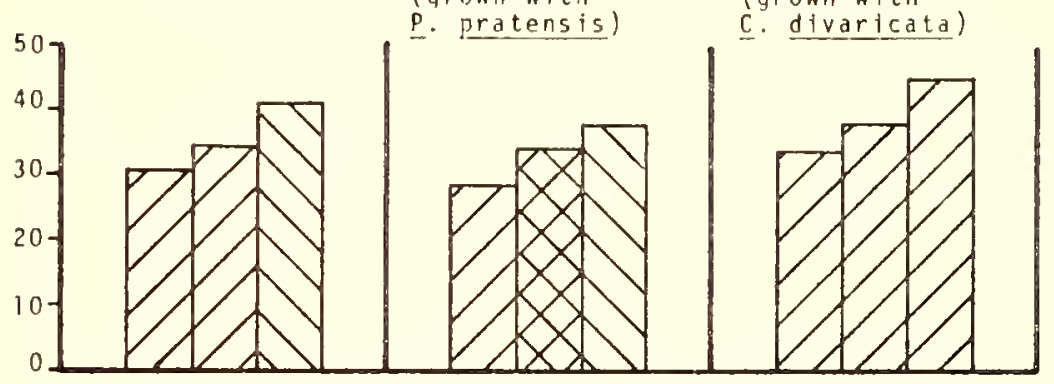

R. fertilts

?

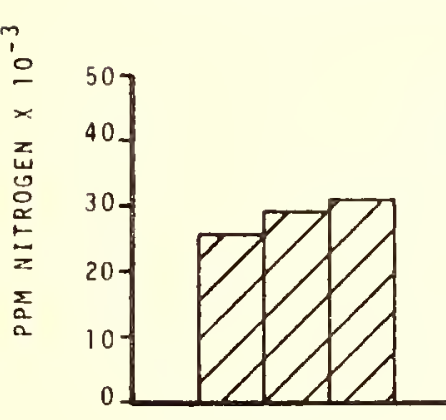

R. fertilis

p. pratensis)

Torown with

C. divaricata)

E. umbellata
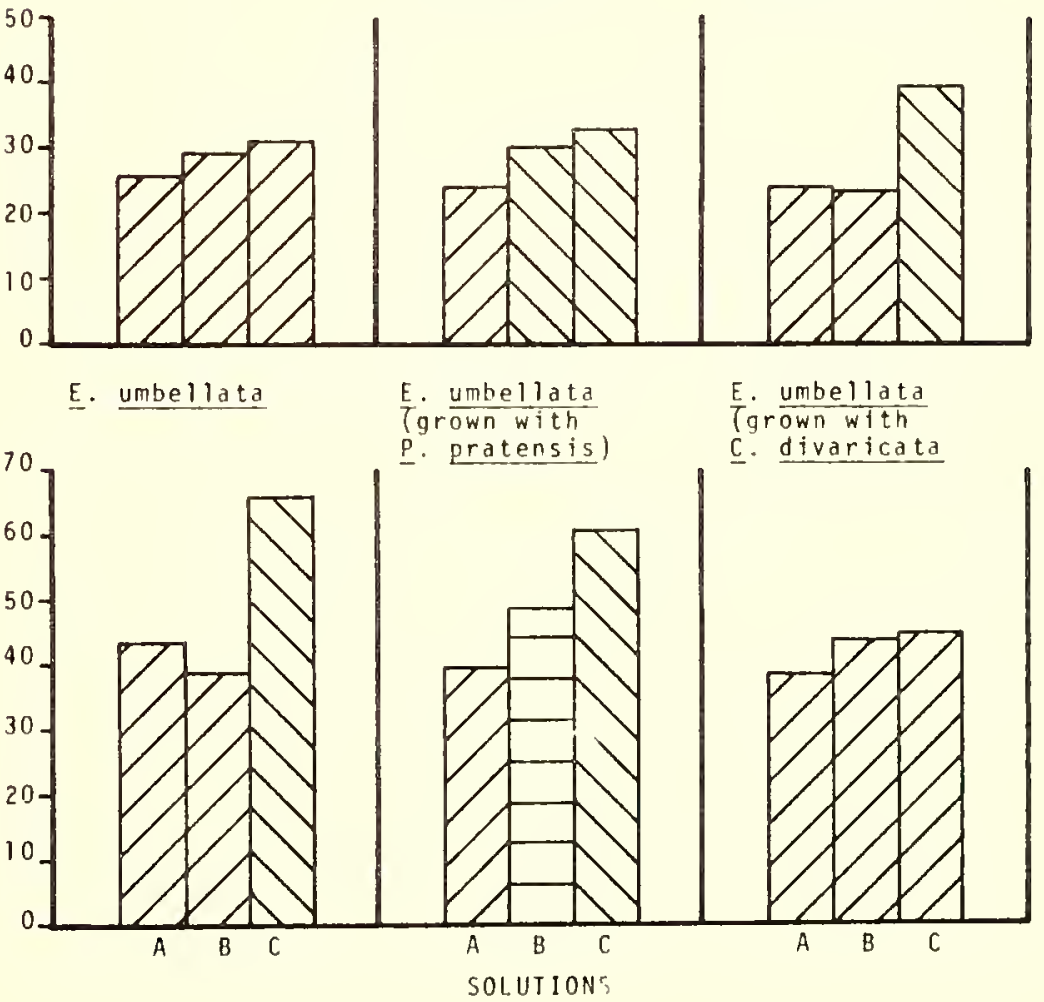

Figure 17. Nitrogen content of foliage of plants grown on three nutrient solutions. 
nutrient levles. E. umbellata, where a high per cent of the plants grown at low or no nitrogen levels survived, the plants even though actively nodulated contained significantly less nitrogen in the foliage when compared to the plants grown with the normal solution. In this case there may have been luxury co sumption of nitrogen, for the plants with less nitrogen also appeared in good or excellent condition.

\section{SUMMARY AND CONCLUSIONS}

By the acetylene reduction assay, nodules from eleven tree and shrub species were found to be active. Activity can be classified from poor to good by the dark to bright nodule color. Nitrogen fixation is dependent on temperature, and even though plants had dropped their leaves due to cold temperatures, nodule activity was able to continue at a reduced rate.

As a nurse crop, it was found that nitrogen-fixing plants do not give off nitrogen through the nodules into the rooting medium while the plant is actively growing. The increase in soil nitrogen around these plants as reported in the literature must come from elsewhere, such as dead and decomposing nodules or from leaf litter.

The nitrogen fixing woody species are capable of providing adequate nitrogen for plant growth. Over a period of time they will build up nitrogen supplies where grown on newly exposed or otherwise low fertility soils. Therefore, landscape architects or other plant 
growers should consider using nitrogen fixing plants in areas of low soil fertility and areas not accessible to frequent of adequate fertilization. 


\section{BIBLIOGRAPIYY}

1. Alexander, M. 1967. Introduction to soil microbiology. John Wiley \& Sons, Inc, New York.

2. Aprison, M. H. and R. H. Burris. 1952. Time course of fixation of $\mathrm{N}_{2}$ by excised soybean nodules. Science 115: 264-265.

3. Biology of alder. 1968. J. M. Trappe, J. F. Franklin, R. F. Tarrant, G. M. Ilansen (ed.), Pacific Northwest Forest \& Range Exp. Sta., Portland, Oregon.

4. Bond, G. 1955. An isotopic study of he fixation of nitrogen associated with nodulated plants of Alnus, Myrica, and Hippophae. Journ Expt1. Bot. 6: 303-311.

5. Bond, G. 1956. Evidence for fixation of nitrogen by root nodules of alder (Alnus). New Phyt. 55: 147-153.

6. Bond, G. 1957. Isotopic studies of nitrogen fixation in nonlegume root nodules. Ann. Bot. 21: 513-521.

7. Bond, G. 1958. Symbiotic nitrogen fixation by non-legumes. In E. G. Hallsworth (ed.), Nutrition of the legumes. Academic Press Inc., New York.

8. Bond, G. 1959. Fixation of nitrogen in non-legume root nodule plants. Soc. Exper. Biol. Symposia 13: 59-72.

9. Bond, G. 1964. Isotopic Investigations of nitrogen fixation in non-1egume root nodules. Nature 204: 600-601.

10. Bond, G. 1967. Fixation of nitrogen by higher plants other than 1egumes. Ann. Rev. Plant Physiol. 18: 107-126.

11. Bond, G., W. W. Fletcher, and T. P. Ferguson. 1954. The development and function of the root nodules of Alnus Myrica and Hippophae. Plant and Soil 5: 309-323.

12. Climalogica1 Data, 19/1. Indiana Station: West Lafayette $6 \mathrm{NW}$. U.S. Dept. Commerce, Environmental Data Service, Asheville, N. C. 76 : No. 10 , No. 11 , and No. 12 .

13. Crocker, R. I. and J. Major. 1955. Soil development and surface age at Glacier Bay, Alaska. J. Ecol. 43: 427-448. 
14. Daly, G. T. 1966. Nitrogen fixation by nodulated Alnus rugosa. Can. J. Botany 44: 1607-1621.

15. Davidson, F. 1970. The influence of rhizobial strain and soybean variety on leghemoglobin, hematin, nodule weights, and nitrogen fixation. Ph. D. Thesis, Purdue University, Lafayette, Indiana.

16. Delver, P. and A. Post. 1968. Influence of alder hedges on the nitrogen $n_{u}$ trition of apple trees. Plant and Soil 28(2): 325-336.

17. Erdman, L. W. 1959. Legume inoculation, what it is--what it does. Farmers' Bulletin 2003. U. S. Dept. Agriculture. Washington, D.C.

18. Ferguson, T. P. and G. Bond. 1953. Observations on the formation and function of the root nodules of Alnus glutinosa (L.) Gaertn. Ann. Bot. 17: 175-188.

19. Fletcher, W. W. 1955. The development and structure of the root nodules of Myrica gale L. with special reference to the nature of the endophyte. Ann. Bot. 19: 501-513.

20. Gardner, I. C. 1958. Nitrogen fixation in Elaeagnus root nodules. Nature 181: 717-718.

21. Goldman, G. M. 1961. The contribution of alder trees (Alnus tenuifolia) to the primary production of Castle Lake, California. Ecology 42: 282-288.

22. Hawker, I. E. and J. Fraymouth. 1951. A re-investigation of the root nodules of species of Elacagnus, Hippophae, Alnus and Myrica, with special reference to the morphology and life histories of the causative organisms. J. Gen. Microbiol. 5: $369-386$.

23. Hoagland, D. R. and D. I. Arron. 1938. The water culture method for growing plants without soil. Univ. Calif. Agr. Exp. Sta. Circ. 347: 1-39.

24. Kohnke, H. 1941. The black alder as a pioneer tree on sand dunes and eroded 1and. J. Forestry 39: 333-334.

25. Lawrence, D. B. 1958. Glaciers and vegetation in southeastern Alaska. American Scientist $46(6):$ 89-122.

26. MacConne11, J. T. and G. Bond. 1957. A comparison of the effect of combined nitrogen on nodulation in non-legumes and legumes. Plant and Soil 8: 378-388. 
27. Meyer, M. M. Jr. 1969. External and internal nutrition and spring growth of woody ornamental plants. Proc. Int. Plant Prop. Soc. 19: $300-305$.

28. Meyer, M. M. Jr. and W. E. Splittstoesser. 1969. The utilization of carbohydrate and nitrogen reserves in the spring growth of 1ilac. Physiol. Plant. 22: 870-879.

29. Meyer, M. M. Jr. and W. E. Splittstoesser. 1971. The utilization of carbohydrate and nitrogen reserves by Taxus during its spring growth period. Physiol. Plant. 24: 306-314.

30. Nelson, D. W. and L. E. Sommers. Determination of total nitrogen in plant material. Submitted to: Agron. Jour.

31. Newton, M., B. A. El Hassan, J. Zavitkovski. 1968. Role of red alder in western Oregon forest succession, p. 73-84. In J. M. Trappe, J. F. Franklin, R. F. Tarrant, and G. M. Hansen (ed.), Biology of alder. Pacific Northwest Forest \& Range Exp. Sta., Portland, Oregon.

32. Quispe1, A. 1958. Symbiotic nitrogen fixation in non-leguminous plants IV. The influence of some environmental conditions on different phases of the nodulation process in Alnus glutinosa. Acta Bot. Neer1. 7: 191-204.

33. Rehder, A. 1967. Manual of cultivated trees and shrubs. Macmillian Co., New York.

34. Rodriquez-Barrueco, C. 1968. The occurence of nitrogen-fixing root nodules on non-leguminous plants. Bot. J. Linn. Soc. 62: $77-84$.

35. Stewart, W. D. P., G. P. Fitzgerald, and R. H. Burris. 1967. In situ studies on $\mathrm{N}_{2}$ fixation using the acetylene reduction technique. Proc. Nat. Acad. Sci. 58: 2071-2078.

36. Virtanen, A. I. 1957. Investigations on nitrogen fixation by the alder. II. Associated culture of spruce and inoculated alder without combined nitrogen. Physiol. Plant. 10: 164-169.

37. Virtanen, A. I., T. Moisio, and R. H. Burris. 1955. Fixation of nitrogen by nodules excised from illuminated and darkened pea plants. Acta Chem. Scand. 9: 184-186.

38. Warren, J.A. 1910. Additional notes on the number and distrubution of native legumes in Nebraska and Kansas. Bur. Pl. Ind. Circ. 70. U.S. Dept. Agriculture, Washington, D. C. 
39. Wheeler, C. T. 1969. The diurnal flucuation in nitrogen fixation in the nodules of Alnus glutinosa and Myrica gale. New Phytol. 68: 675-782.

40. Wheeler, C. T. 1971. The causation of the diurnal changes in nitrogen fixation in the nodules of Alnus glutinosa. New Phytol. 70: 487-495.

41. Ziegler, H. 1963. Fixation of Atmospheric nitrogen by root nodules of Comptonia peregrina. Nature 194: 508. 
Table LA. Statisti

Treatment

Normal nitrogen

Low nitrogen

No nitrogen

Normal nitrogen

Low nitrogen

No nitrogen

Norma1 nitrogen

\section{Low nitrogen}

No nitrogen

${ }_{\mathrm{E}}^{\mathrm{z}}=$ excellent, $\mathrm{G}$ 
Table LA. Statistics on each plant grown in the solution culture experiment.

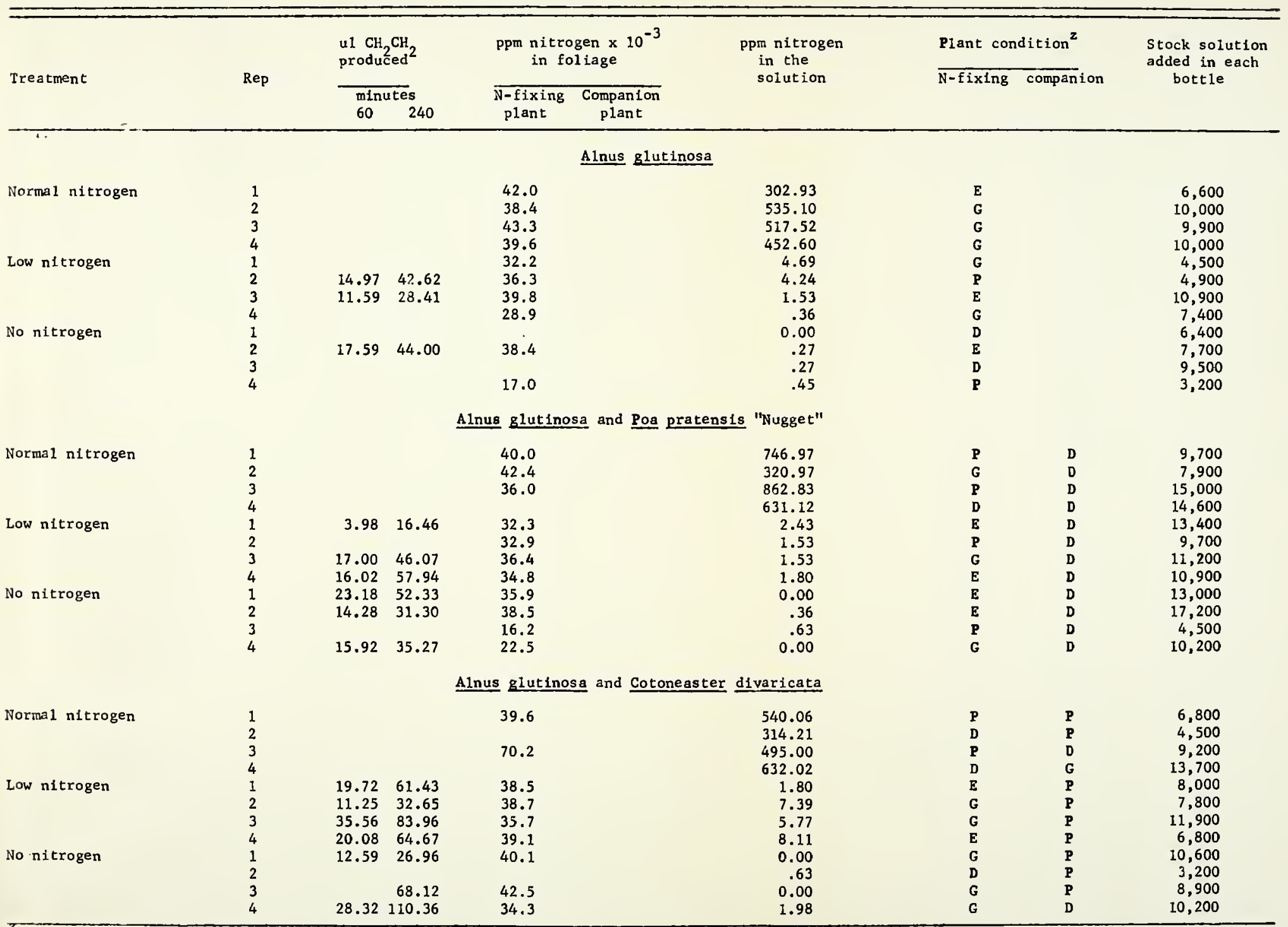


Table IA. Continue

Treatment

Normal nitrogen

Low nitrogen

No nitrogen

Normal nitrogen

Low nitrogen

No nitrogen

Normal nitrogen

Low nitrogen

No nitrogen 


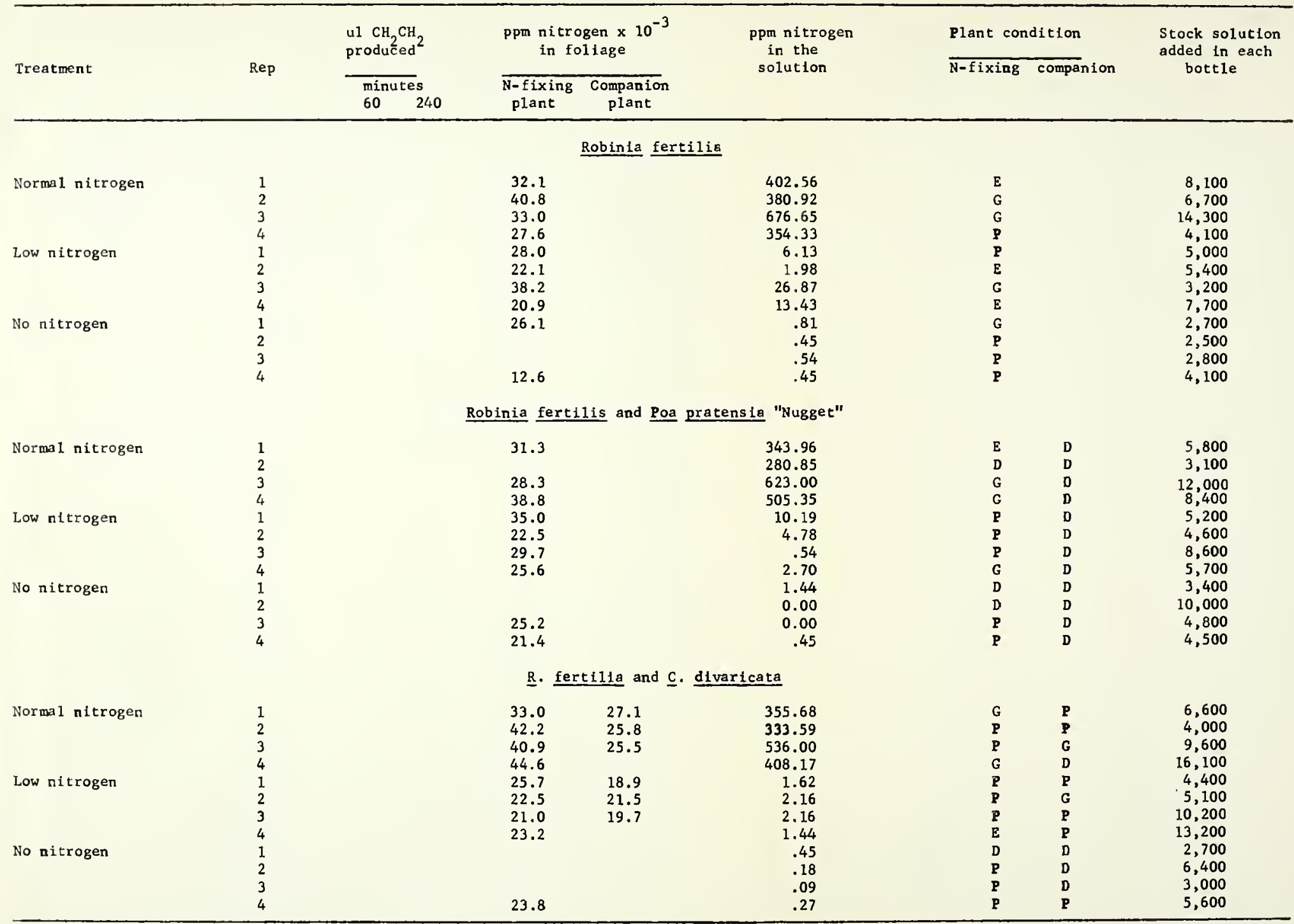


Table 1A. Continue

Treatment

Normal nitrogen

Low nitrogen

No nitrogen

Normal nitrogen

Low nitrogen

No nitrogen

Normal nitrogen

Low nitrogen

No nitrogen 


\begin{tabular}{|c|c|c|c|c|c|c|c|}
\hline \multirow{3}{*}{ Treatment } & \multirow{3}{*}{ Rep } & $\begin{array}{l}\text { uI } \mathrm{CH}_{2} \mathrm{CH} \\
\text { produced }\end{array}$ & \multirow{2}{*}{$\begin{array}{l}\text { Ppm nitrogen } \times 10^{-3} \\
\text { in foliage }\end{array}$} & \multirow{3}{*}{$\begin{array}{l}\text { ppm nitrogen } \\
\text { in the } \\
\text { solution }\end{array}$} & \multicolumn{2}{|c|}{ Plant condition } & \multirow{3}{*}{$\begin{array}{l}\text { Stock solution } \\
\text { added in each } \\
\text { bottle }\end{array}$} \\
\hline & & & & & N-fixing & companion & \\
\hline & & $\begin{array}{l}\text { minutes } \\
60 \quad 240\end{array}$ & $\begin{array}{cc}\text { N-fixing } & \text { Companion } \\
\text { plant } & \text { plant }\end{array}$ & & & & \\
\hline & & & Elaeagnus angus & & & & \\
\hline \multirow{4}{*}{ Norma 1 nitrogen } & 1 & & 54.5 & 247.49 & D & & 4,700 \\
\hline & 2 & & 44.9 & 288.51 & $G$ & & 2,800 \\
\hline & 3 & & 51.7 & 298.88 & P & & 8,300 \\
\hline & 4 & & & 274.08 & D & & 2,300 \\
\hline \multirow[t]{4}{*}{ Low nitrogen } & 1 & & & 18.75 & $\mathbf{P}$ & & 330 \\
\hline & 2 & & & 20.92 & D & & 2,400 \\
\hline & 3 & & 42.8 & 21.64 & $\mathbf{G}$ & & 4,500 \\
\hline & 4 & & & 27.77 & D & & 4,200 \\
\hline \multirow[t]{4}{*}{ No nitrogen } & 1 & & 53.5 & .54 & G & & 1,800 \\
\hline & 2 & sma 11 nodules & 30.3 & 5.32 & G & & 4,700 \\
\hline & 3 & $4.80 \quad 31.83$ & 31.1 & 9.29 & G & & 3,000 \\
\hline & 4 & & & 3.43 & $\mathrm{D}$ & & 3,300 \\
\hline \multicolumn{8}{|c|}{$\underline{E}$. angustifolia and Poa pratensia "Nugget" } \\
\hline \multirow[t]{4}{*}{ Norma 1 nitrogen } & 1 & & & 323.22 & D & D & 3,900 \\
\hline & 2 & & & 247.49 & 8 & D & 3,200 \\
\hline & 3 & & & 348.47 & $\mathbf{P}$ & D & 4,600 \\
\hline & 4 & & 45.1 & 339.90 & G & $D$ & 5,300 \\
\hline \multirow{4}{*}{ Low nitrogen } & 1 & & 38.2 & .63 & $\mathbf{P}$ & D & 3,800 \\
\hline & 2 & sma 11 nodules & 44.5 & 4.42 & 8 & D & 3,400 \\
\hline & 3 & & & 1.08 & $D$ & D & 4,600 \\
\hline & 4 & & & 7.75 & $\mathrm{D}$ & D & 3,200 \\
\hline \multirow[t]{4}{*}{ No nitrogen } & 1 & $15.19 \quad 45.20$ & 47.5 & .54 & $\varepsilon$ & D & 6,400 \\
\hline & 2 & & & 0.00 & D & D & 3,100 \\
\hline & 3 & & 34.6 & .54 & $\mathbb{P}$ & $\mathrm{D}$ & 6,600 \\
\hline & 4 & sma 11 nodules & 29.3 & 0.00 & G & $D$ & 4,500 \\
\hline \multicolumn{8}{|c|}{$\underline{E}$. engustifolia and $\underline{\mathrm{C}}$. divaricata } \\
\hline \multirow[t]{4}{*}{ Norma 1 nitrogen } & 1 & & 25.2 & 294.37 & $\boldsymbol{P}$ & $P$ & 3,000 \\
\hline & 2 & & 24.8 & 343.06 & G & G & 5,500 \\
\hline & 3 & & 27.7 & 289.86 & D & G & 4,000 \\
\hline & 4 & & 27.2 & 289.86 & D & $\mathbf{P}$ & 4,300 \\
\hline \multirow[t]{4}{*}{ Low nitrogen } & 1 & 48.27 & 18.5 & .72 & G & $\mathbf{Z}$ & 5,700 \\
\hline & 2 & & 23.2 & 2.70 & D & G & 5,500 \\
\hline & 3 & & 23.8 & .90 & $\mathbf{P}$ & G & 5,400 \\
\hline & 4 & & 40.5 & 13.43 & D & $P$ & 6,400 \\
\hline No nitrogen & 1 & & 19.2 & .18 & $\mathbf{P}$ & 2 & 4,000 \\
\hline & 2 & & 14.8 & .54 & D. & 2 & 3,300 \\
\hline & 3 & & & 1.44 & D & 2 & 2,900 \\
\hline . & 4 & & & 4.24 & D & $\mathbf{P}$ & 5,300 \\
\hline
\end{tabular}


Table 1A. Continue

Treatment

Normal nitrogen

Low nitrogen

No nitrogen

Normal nitrogen

Low nitrogen

No nitrogen

Normal nitrogen

Low nitrogen

No nitrogen 
Table IA. Continued.

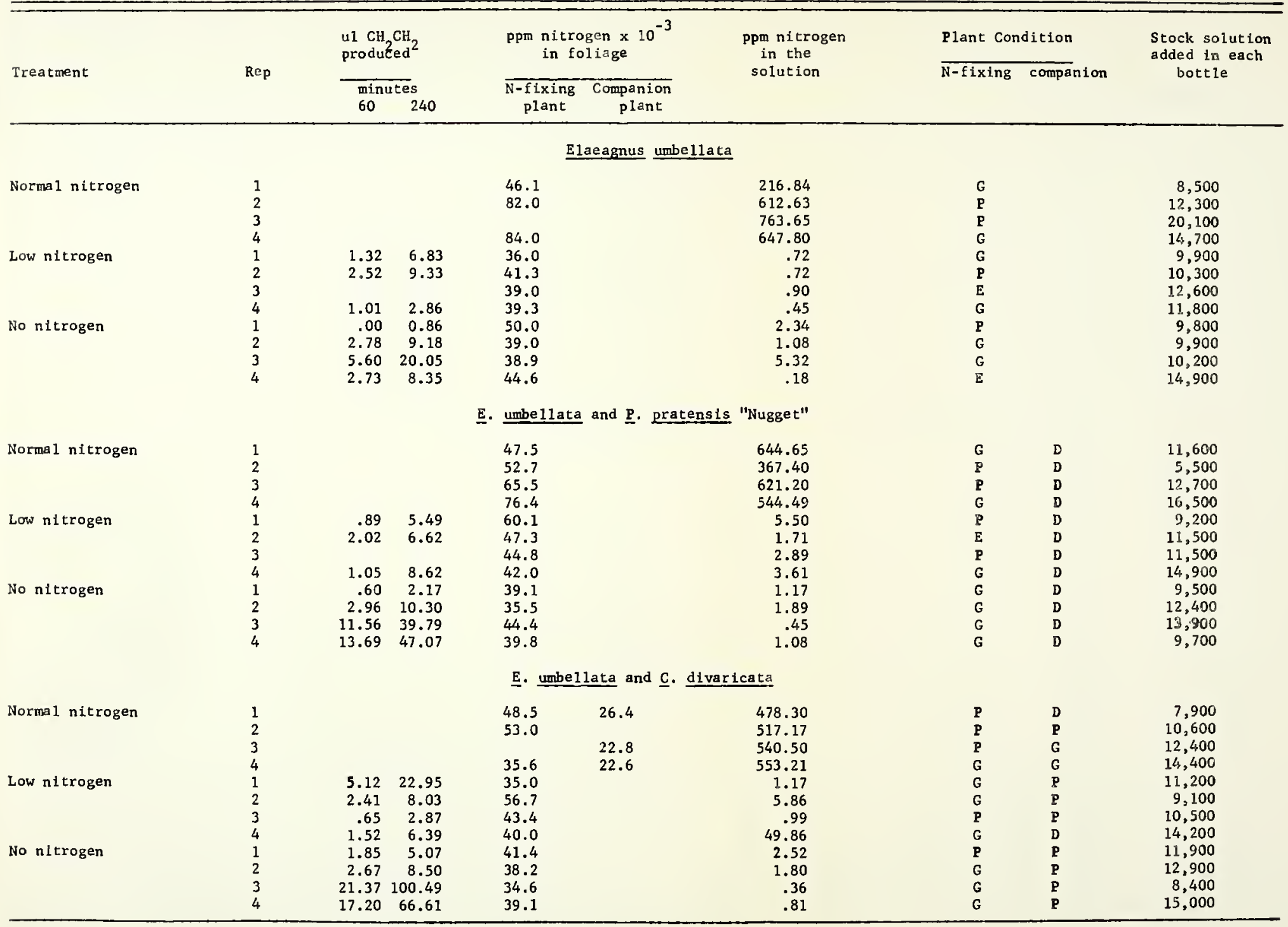


Table 1A. Continue

Treatment

Normal nitrogen

Low nitrogen

No nitrogen

Norma 1 nitrogen

Low nitrogen

No nitrogen

Normal nitrogen

Low nitrogen

No nitrogen

Normal nitrogen

Low nitrogen

No nitrogen 
Table 1A. Continued.

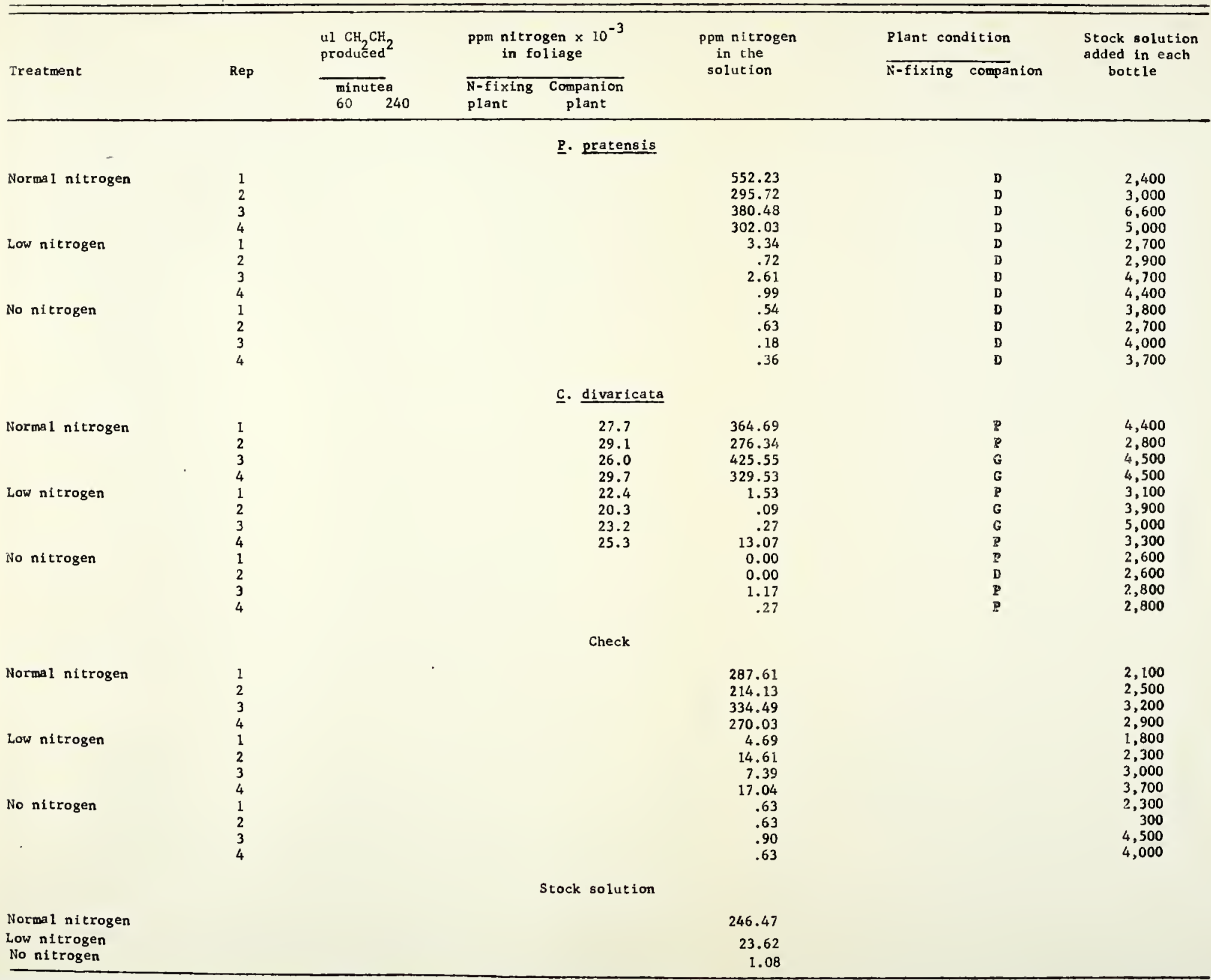


